\title{
Regioselective Mercury(I)/Palladium(II)-Catalyzed Single-Step Approach for the Synthesis of Imines and 2-Substituted Indoles
}

\author{
Rsuini U. Gutiérrez ${ }^{1}$, Mayra Hernández-Montes ${ }^{1}$, Aarón Mendieta-Moctezuma ${ }^{2}$, Francisco Delgado ${ }^{1}$ \\ and Joaquín Tamariz ${ }^{1, *}$ \\ 1 Departamento de Química Orgánica, Escuela Nacional de Ciencias Biológicas, Instituto Politécnico Nacional, \\ Prolongación de Carpio y Plan de Ayala s/n, Mexico City 11340, Mexico; rsuini.uri@gmail.com (R.U.G.); \\ encb.mayra2020@gmail.com (M.H.-M.); jfdelgador@gmail.com (F.D.) \\ 2 Centro de Investigación en Biotecnología Aplicada, Instituto Politécnico Nacional, Carretera Estatal Santa \\ Inés Tecuexcomac-Tepetitla, Km 1.5, Tlaxcala 90700, Mexico; amendieta@ipn.mx \\ * Correspondence: jtamarizm@gmail.com or jtamarizm@ipn.mx
}

\section{check for}

updates

Citation: Gutiérrez, R.U.;

Hernández-Montes, M.;

Mendieta-Moctezuma, A.; Delgado,

F.; Tamariz, J. Regioselective

Mercury(I)/Palladium(II)-Catalyzed Single-Step Approach for the Synthesis of Imines and 2-Substituted Indoles. Molecules 2021, 26, 4092. https://doi.org/10.3390/molecules 26134092

Academic Editor: Lucia Veltri

Received: 4 June 2021

Accepted: 29 June 2021

Published: 5 July 2021

Publisher's Note: MDPI stays neutral with regard to jurisdictional claims in published maps and institutional affiliations.

Copyright: (C) 2021 by the authors Licensee MDPI, Basel, Switzerland. This article is an open access article distributed under the terms and conditions of the Creative Commons Attribution (CC BY) license (https:// creativecommons.org/licenses/by/ $4.0 /)$.

\begin{abstract}
An efficient synthesis of ketimines was achieved through a regioselective $\mathrm{Hg}(\mathrm{I})$-catalyzed hydroamination of terminal acetylenes in the presence of anilines. The $\mathrm{Pd}(\mathrm{II})$-catalyzed cyclization of these imines into the 2-substituted indoles was satisfactorily carried out by a C-H activation. In a single-step approach, a variety of 2 -substituted indoles were also generated via a $\mathrm{Hg}(\mathrm{I}) / \mathrm{Pd}(\mathrm{II})$-catalyzed, one-pot, two-step process, starting from anilines and terminal acetylenes. The arylacetylenes proved to be more effective than the alkyl derivatives.
\end{abstract}

Keywords: mercury(I)-catalyzed alkyne hydroamination; imines; Pd-catalyzed oxidative cyclization; one-pot indole synthesis

\section{Introduction}

Imines are one of the most versatile functional groups in synthesis. Numerous studies have focused on their preparation [1-5], chemical structure and tautomeric or transimination equilibrium [6-8], and use as a precursor for the construction of more complex structures [9-12]. Due to their versatility, they play an important role in medicinal chemistry, serving as urease and protease inhibitors [13] as well as antimalarial, antibacterial, and antifungal agents [14]. They also exhibit activity against Mycobacterium tuberculosis [15] and tumor cells [16-19], and act as suppressors of HIV1-gp120, related to the human immunodeficiency virus (HIV) [20] (Figure 1). Interestingly, imines are present in phytoplankton and shellfish as toxins [21].

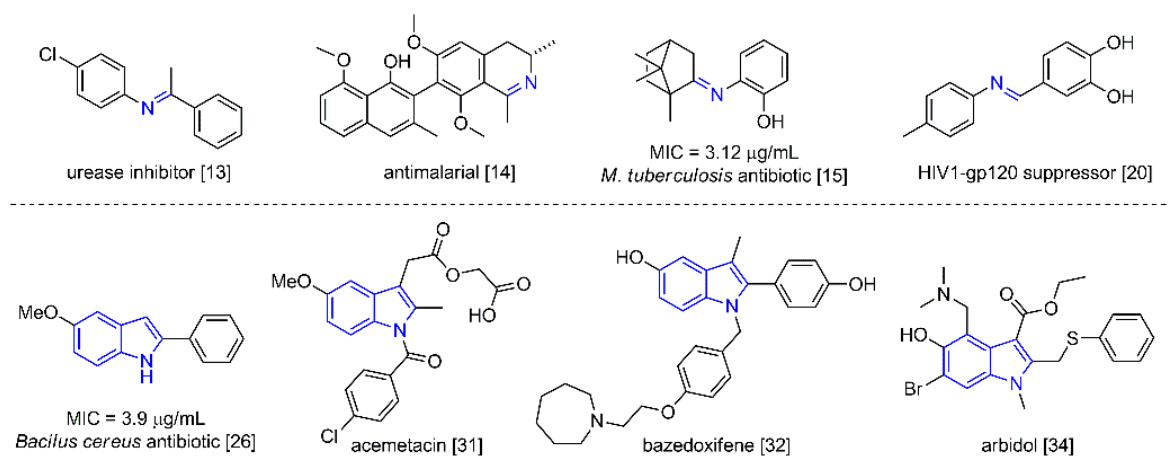

Figure 1. Imine- and indole-containing compounds with pharmacological activity.

Likewise, indoles are widely distributed in natural products [22-24]. They occupy a prominent place as pharmacologically active compounds [25-28], including commercial therapeutic chemicals and active pharmaceutical ingredients [29-31]. The U.S. Food and 
Drug Administration (FDA) has approved at least 43 indole-containing drugs [32,33]. For example, arbidol has shown efficient in vitro activity against the SARS-CoV-2 infections [34] and has been administered to infected patients [35-37] (Figure 1). Hence, the molecular structures of imines and indoles are of great value for medicinal and synthetic purposes.

Despite the variety of methods for the preparation of imines [1-5], their synthesis is mainly carried out with conventional procedures, such as the acid-catalyzed condensation of a carbonyl compound with a primary amine [1]. Among the relevant methodologies are the reduction of nitriles, oximes, and aliphatic nitro derivatives [38-41], the addition of an organometallic reagent to nitriles and amides [42,43], and the oxidation of alcohols and amines $[44,45]$. These methods are only practical, however, if there is an existing carbon-nitrogen formal bond in the substrate.

Intermolecular imine is usually synthesized by condensation reactions with an azeotropic agent [1], a desiccant [46], or a water scavenger [47] to remove water. Alkyne hydroamination arose as an alternative, being an attractive and elegant pathway with complete atom economy [48-51]. Barluenga et al. described several catalytic and noncatalytic hydroamination methods with terminal acetylenes (e.g., 2a) promoted by $\mathrm{Tl}(\mathrm{III})$ or $\mathrm{Hg}$ (II) salts [52]. They found that $\mathrm{HgCl}_{2}$ acts through a nucleophilic attack of the aniline (1a) on the internal acetylene carbon, firstly forming terminal acetylene- $\mathrm{HgCl}$ complex 3 followed by its possible conversion into the aminoalkenylmercurial(II) chloride intermediate 4 . The latter regenerates the $\mathrm{Hg}$ (II) catalyst by protonolysis to give the enamine, which is converted into the desired imine 5a (Scheme 1a) [53,54].

a) $\mathrm{Hg}$ (II)-catalyzed alkyne hydroamination for imine synthesis Barluenga et al., $1980 \& 1983[53,54]$

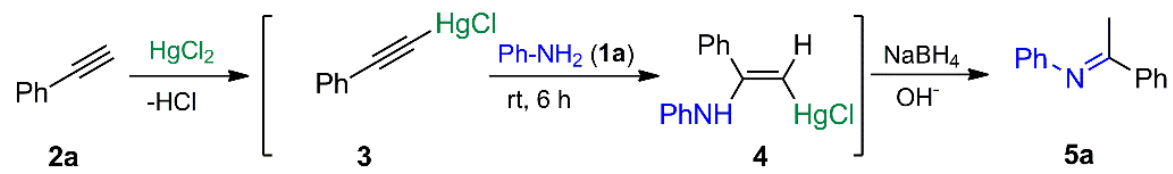

b) Imine oxidative cyclization for indole synthesis

Yoshikai et al., 2012 [66]

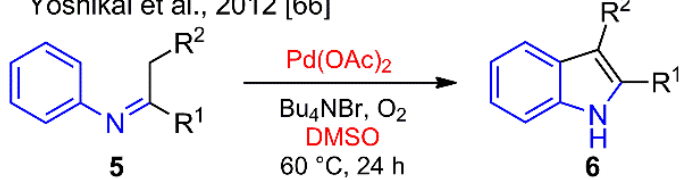

Xiao et al., 2018 [67]

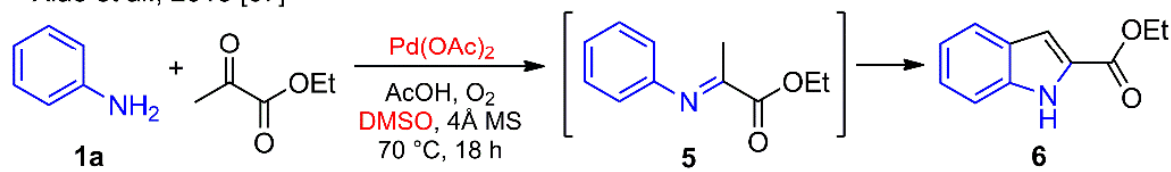

Zhang et al., 2020 [68]

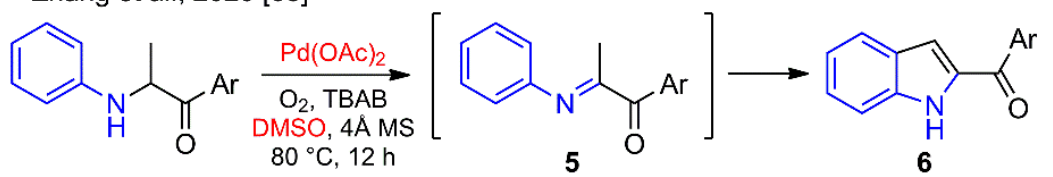

c) This work: indole synthesis by a one-pot alkyne hydroamination/imine oxidative cyclization

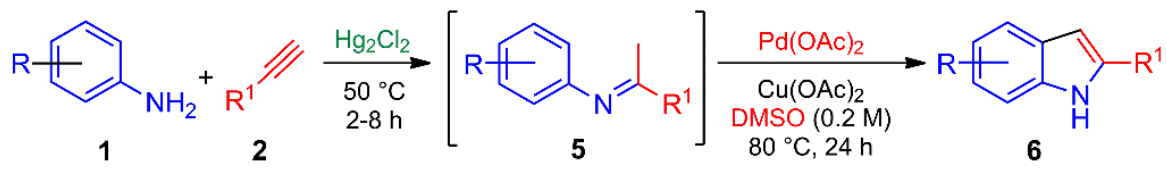

Scheme 1. (a) Imine synthesis by a $\mathrm{Hg}$ (II)-promoted alkyne hydroamination. (b) Indole synthesis from imines derived by a condensation reaction and Pd(II)-catalyzed oxidative cyclization. (c) Pd(II)catalyzed indole synthesis from imines derived from $\mathrm{Hg}(\mathrm{I})$-catalyzed alkyne hydroamination. 
In contrast, indoles have been elaborated by diverse protocols [55], such as the wellknown Fischer [56,57], Julia [58], Bartoli [59], and Gassman [60] procedures, each of which include a sigmatropic rearrangement at a high temperature. Other efficient approaches have involved organometallic reagents, as with the syntheses of indoles described by Castro [61], Larock [62], Fagnou [63], and Söderberg [64,65]. Most of them demand the use of ortho-halogenated and ortho-vinylated $\mathrm{N}$-protected anilines or nitrobenzenes to build the indole A ring. Recently, imine substrates have proven valuable for indole synthesis, as demonstrated by the groups of Yoshikai [66], Xiao [67], and Zhang [68] (Scheme 1b).

Our group has an ongoing interest in designing and carrying out the novel synthesis of heterocycles [69-71], and in particular of aza-heterocycles and indoles [72-75]. Accordingly, the aim of the present study was to assess the feasibility of preparing indoles in a one-pot process, involving the regioselective $\mathrm{Hg}(\mathrm{I})$-catalyzed hydroamination of terminal alkynes to produce imines as intermediates, and their subsequent $\mathrm{Pd}(\mathrm{II})$-catalyzed cross-coupling oxidative cyclization to afford the corresponding C-2-substituted indoles (Scheme 1c).

\section{Results and Discussion}

\subsection{Synthesis of Imines $\mathbf{5 a} \boldsymbol{a} \boldsymbol{n}$ by $\mathrm{Hg}(\mathrm{I})$-catalyzed Hydroamination of Alkynes $\mathbf{2} \boldsymbol{a}-\boldsymbol{d}$ with} Anilines $1 a-k$

The properties of $\mathrm{Hg}(0)$ and $\mathrm{Hg}(\mathrm{II})$ salts have been examined [76], and these species have many chemical and industrial applications [77-79], including chemical transformations [80-82]. Curiously, the use of $\mathrm{Hg}(\mathrm{I})$ in organic synthesis is surprisingly rare and limited $[83,84]$. Our group has reported the inclusion of $\mathrm{Hg}_{2} \mathrm{Cl}_{2}$ as the catalyst for the solvent-free hydroamination of phenylacetylene (2a) with $m$-anisidine (1e) to furnish the corresponding imine 5e in quantitative yield [85]. Following up on that effort, the scope of the method was herein explored by varying the structure of anilines (1) and acetylenes (2) to develop an efficient synthesis of imines (5). Unfortunately, when employing the previously described reaction conditions (room temperature, $24 \mathrm{~h}$ ), the yields of the resulting imines depended on the anilines (Table 1). For example, with $p$-anisidine (1i) and 2a, imine 5i was furnished in a modest yield (61\%, entry 2$)$. The yield was improved by increasing the reaction time $(82 \%$, entry 3$)$ or by raising the temperature to $45^{\circ} \mathrm{C}$ with a reaction time of $4 \mathrm{~h}(87 \%$, entry 4$)$.

Table 1. Optimization of the preparation of $N$-arylimines $5 \mathbf{e}$ and $5 \mathbf{i}^{\text {a }}$.

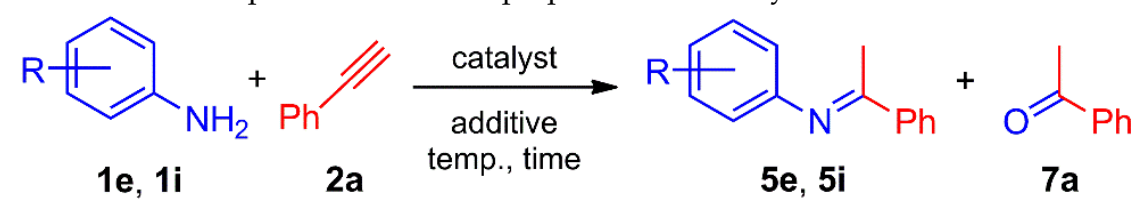

\begin{tabular}{|c|c|c|c|c|c|c|}
\hline Entry & 1 (Ar) & Catalyst & $\begin{array}{c}\text { Additive } \\
\text { (mol equiv.) }\end{array}$ & $\mathrm{T}\left({ }^{\circ} \mathrm{C}\right)$ & $\mathbf{T}(\mathbf{h})$ & 5 (Yield, \%) \\
\hline 1 & 1e $\left(\mathrm{C}_{6} \mathrm{H}_{4}-3-\mathrm{OMe}\right)$ & $\mathrm{Hg}_{2} \mathrm{Cl}_{2}$ & - & 20 & 24 & $5 e(99)^{c}$ \\
\hline 2 & $\mathbf{1 i}\left(\mathrm{C}_{6} \mathrm{H}_{4}-4-\mathrm{OMe}\right)$ & $\mathrm{Hg}_{2} \mathrm{Cl}_{2}$ & - & 20 & 24 & $5 \mathbf{i}(61)^{d}$ \\
\hline 3 & $\mathbf{1 i}\left(\mathrm{C}_{6} \mathrm{H}_{4}-4-\mathrm{OMe}\right)$ & $\mathrm{Hg}_{2} \mathrm{Cl}_{2}$ & - & 20 & 48 & $5 \mathbf{i}(82) d$ \\
\hline 4 & $\mathbf{1 i}\left(\mathrm{C}_{6} \mathrm{H}_{4}-4-\mathrm{OMe}\right)$ & $\mathrm{Hg}_{2} \mathrm{Cl}_{2}$ & - & 45 & 4 & $5 \mathbf{i}(87) \mathrm{d}$ \\
\hline 5 & 1e $\left(\mathrm{C}_{6} \mathrm{H}_{4}-3-\mathrm{OMe}\right)$ & $\mathrm{Ag}_{2} \mathrm{CO}_{3}$ & - & 20 & 72 & $5 e(0) d$ \\
\hline 6 & $\mathbf{1 i}\left(\mathrm{C}_{6} \mathrm{H}_{4}-4-\mathrm{OMe}\right)$ & $\mathrm{Hg}_{2} \mathrm{Cl}_{2}$ & - & 60 & 2 & $5 \mathbf{i}(72)$ \\
\hline $7^{e}$ & $\mathbf{1 i}\left(\mathrm{C}_{6} \mathrm{H}_{4}-4-\mathrm{OMe}\right)$ & $\mathrm{Hg}_{2} \mathrm{Cl}_{2}$ & $\mathrm{Li}_{2} \mathrm{CO}_{3}(0.2)$ & 60 & 2 & $5 \mathbf{i}(91)$ \\
\hline $8^{e}$ & $\mathbf{1 i}\left(\mathrm{C}_{6} \mathrm{H}_{4}-4-\mathrm{OMe}\right)$ & $\mathrm{Hg}_{2} \mathrm{Cl}_{2}$ & $\left(f^{f}\right)$ & 60 & 2 & $5 \mathbf{i}(70)$ \\
\hline $9^{\mathrm{e}}$ & $\mathbf{1 i}\left(\mathrm{C}_{6} \mathrm{H}_{4}-4-\mathrm{OMe}\right)$ & $\mathrm{HgCl}_{2}$ & $\mathrm{Li}_{2} \mathrm{CO}_{3}(0.2)$ & 60 & 2 & $5 \mathbf{i}(78)$ \\
\hline $10^{\mathrm{e}}$ & $\mathbf{1 i}\left(\mathrm{C}_{6} \mathrm{H}_{4}-4-\mathrm{OMe}\right)$ & $\mathrm{Hg}^{0}$ & $\mathrm{Li}_{2} \mathrm{CO}_{3}(0.2)$ & 60 & 2 & $5 \mathbf{i}(0)$ \\
\hline
\end{tabular}

${ }^{a} 2$ a (1.0 mol equiv.), $\mathrm{ArNH}_{2}$ (1.0-1.1 mol equiv.), catalyst (10 mol\%), and no solvent. ${ }^{\mathrm{b}}$ After purification by column chromatography. ${ }^{\mathrm{c}}$ [85].

${ }^{\mathrm{d}}$ Calculated by ${ }^{1} \mathrm{H}$ NMR of the reaction crude mixture. ${ }^{\mathrm{e}}$ Catalyst (5.0 mol\%). ${ }^{\mathrm{f}}$ Hydroquinone (0.5 mol equiv.).

Other parameters were evaluated, such as solvent, catalyst, and additive. Although solvent-free reaction conditions are always recommended for designing an optimal green 
chemistry methodology [86], three chlorinated solvents (chloroform, 1,2-dichloroethane, and methylene chloride), THF, and DMSO were assessed by heating at $60^{\circ} \mathrm{C}$ for $2-12 \mathrm{~h}$. Whereas imine $5 \mathbf{i}$ was obtained in fairly low yields (21-41\%) with either the first or the third solvent, it was not detected with 1,2-dichloroethane, THF, and DMSO. When $\mathrm{Ag}_{2} \mathrm{CO}_{3}$ (Table 1, entry 5) and $\mathrm{CuCl}$ (not shown) were tested as the catalysts for $\mathbf{1 e}$ and $\mathbf{2 a}$, the outcome was the recovery of the reactants but no trace of imine $5 \mathbf{e}$.

Imines, usually water-sensitive, are converted into ketones by hydrolysis. For example, acetophenone (7a) can be formed from imines $5 \mathbf{e}$ or $\mathbf{5 i}$. Therefore, anhydrous lithium carbonate was employed as the additive, which greatly improved the yield (Table 1 , entries 6 and 7). Of course, under these optimal reaction conditions, the presence of $\mathrm{Hg}_{2} \mathrm{Cl}_{2}$ was essential for the transformation to take place. Due to a feasible light-induced $\mathrm{Hg}-\mathrm{Hg}$ bond disproportionation [87], the generation of radicals was contemplated. Consequently, hydroquinone was added as a radical quencher, which did not modify the yield (entry 8) and thus ruled out this possibility.

In agreement with the findings of Barluenga et al. [52-54], the process was also catalyzed with $\mathrm{HgCl}_{2}$ under the same reaction conditions, but a lower yield $(78 \%)$ was observed (Table 1, entry 9). This suggests that $\mathrm{Hg}(\mathrm{I})$ and $\mathrm{Hg}(\mathrm{II})$ are both probably the catalytic species involved in the process. Considering the feasible generation of $\mathrm{Hg}(0)$ as a secondary product during the decomposition of $\mathrm{Hg}_{2} \mathrm{Cl}_{2}$ under an analogous reaction $[53,54]$, the process was carried out in the presence of $\mathrm{Hg}(0)$, but no imine was found (entry 10). Hence, the participation of $\operatorname{Hg}(0)$ as a catalyst is unlikely. Moreover, there was no visual evidence of a dark-silver mirror residue in the $\mathrm{Hg}(\mathrm{I})$ trials. Actually, $\mathrm{Hg}(0)$ is a well-known poisoning catalyst in heterogeneous/homogeneous reactions [88].

To gain insights into the mechanism, 2a was reacted with $\mathrm{Hg}_{2} \mathrm{Cl}_{2}$ to examine its possible conversion into acetophenone (7a) as an intermediate. After heating at $45^{\circ} \mathrm{C}$ for $1 \mathrm{~h}$, however, only the recovery of $\mathbf{2 a}$ was achieved. Taking into account the potential formation of intermediate $\mathbf{7 a}$ in the middle of the reaction, a further trial was performed under the same reaction conditions $\left(45^{\circ} \mathrm{C}\right.$ for $1 \mathrm{~h}$ ) and in the presence of $1 \mathbf{i}$ and $\mathrm{Hg}_{2} \mathrm{Cl}_{2}$. The result was again the recovery of the staring material. Finally, after reacting a mixture of $1 \mathbf{i}$ and $\mathrm{Hg}_{2} \mathrm{Cl}_{2}$ at $45^{\circ} \mathrm{C}$ for $1 \mathrm{~h}$, no N-Hg complex was detected.

Once the reaction conditions were optimized (Table 1, entry 7), evaluation was performed for a series of anilines (1a-k) bearing substituents with diverse electron-demand at the three positions of the benzene ring, utilizing arylalkynes $\mathbf{2 a -} \mathbf{d}$ as the terminal acetylenes (Table 2). In general, neither the electron-demand of the substituents nor their position in the benzene ring of the aniline showed any effect on the efficacy of the process. The only exception was the use of the halogenated anilines $1 \mathbf{f}$ and $\mathbf{1 k}$, which gave rise to the corresponding imines in modest yields (Table 2, entries 6 and 11).

The high yields afforded by the unsubstituted phenylacetylene (2a) were also obtained with the terminal para-substituted phenylacetylenes $\mathbf{2 b}$-d (Table 2, entries 9 and 12-14), supporting the idea that $\mathrm{Hg}(\mathrm{I})$ easily interacts with the triple bond regardless of the electron-demand of its substituent. Furthermore, the reaction was successful with terminal alkyl- and some aryl-acetylenes, including 4-cyanophenylacetylene (2c), propylacetylene (2e), cyclopropylacetylene (2f), and cyclohexylacetylene (2g), judging by the ${ }^{1} \mathrm{H}$ NMR and MS/GC analyses of the crude mixtures. Nevertheless, the corresponding imines $5 \mathrm{~m}$ (as a mixture of $5 \mathrm{~m} / p$-cyanoacetophenone (7b) (95:5)) and 5o-q were not stable enough to be isolated under the extraction conditions. Evidence of their formation was found unambiguously by the synthesis of the indoles (see Scheme 3).

Reactivity significantly decreased with the di-substitution of the triple bond. For instance, neither methylpropylacetylene ( $2 \mathbf{h}$ ) nor phenylpropylacetylene (2i) reacted with $p$-anisidine (1i), even when the mixture was heated to $80^{\circ} \mathrm{C}$ for $53 \mathrm{~h}$, probably because both electronic and steric effects impede the addition of the aniline or do not allow for the formation of the $\sigma-\mathrm{Hg}(\mathrm{I})$-acetylene complex (see below). 
Table 2. Preparation of the series of $N$-arylimines $\mathbf{5 a}-\mathbf{n}$ through the $\mathrm{Hg}(\mathrm{I})$-catalyzed hydroamination of $\mathbf{2} \mathbf{a}-\mathbf{d}$ with anilines $\mathbf{1} \mathbf{a}-\mathbf{k}^{\mathrm{a}}$.

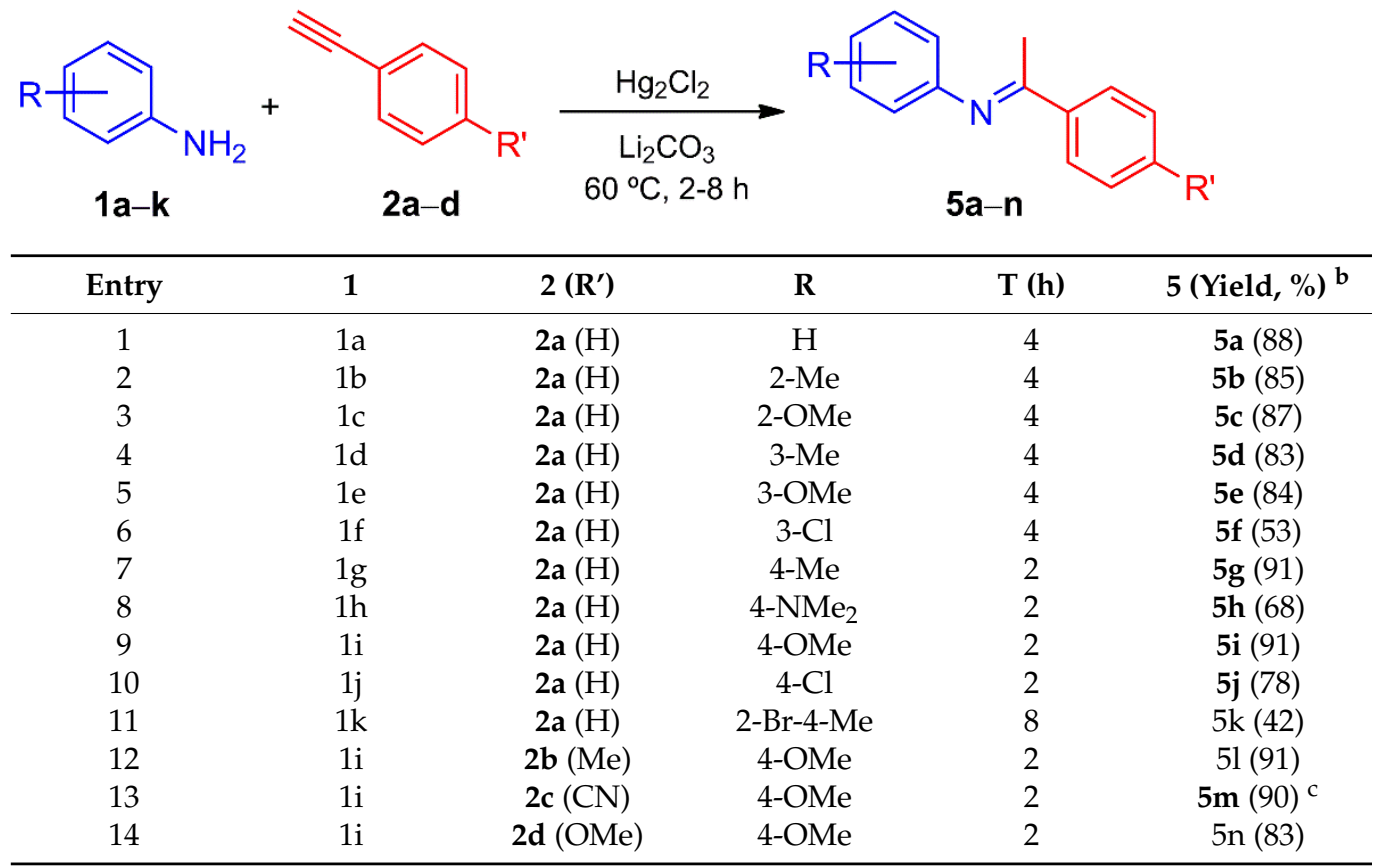

a 2 (1.0 mol equiv.), $\mathrm{ArNH}_{2}$ (1.0-1.1 mol equiv.), $\mathrm{Hg}_{2} \mathrm{Cl}_{2}$ (5 mol\%), $\mathrm{Li}_{2} \mathrm{CO}_{3}\left(0.2\right.$ mol equiv.), and no solvent. ${ }^{\mathrm{b}}$ After purification by column chromatography. ${ }^{c}$ The yield was estimated from the ${ }^{1} \mathrm{H}$ NMR spectrum of the crude reaction mixture, resulting in the ratio products, which were then confirmed by the ratio and molecular ions by MS/GC analysis. The product was not isolated and used without purification in the next step.

All the imines prepared by this method were characterized by IR and NMR (1D and 2D), and in some cases, HRMS. The latter technique was performed in case of finding a discrepancy between the data reported in the literature and the melting point or physical state of the compound in the current effort. Imine $5 \mathbf{i}$ was crystallized in order to be subjected to X-ray crystallographic analysis (Figure 2), which demonstrated the expected $E$ configuration of the double bond. However, the $\mathrm{N}$-anisyl ring was not coplanar to the imine double bond, instead adopting a quasi-orthogonal conformation (torsion angle, $\mathrm{C}(8)-\mathrm{N}(1)-\mathrm{C}(1)-\mathrm{C}(2)=115.31(17)$, see Supplementary Materials), which indicates that the $\pi$-system is not conjugated. In contrast, the phenyl ring attached to the imine double bond displayed a planar conformation (torsion angle, $\mathrm{C}(11)-\mathrm{C}(10)-\mathrm{C}(8)-\mathrm{N}(1)=-4.7(2)$, see Supplementary Materials).

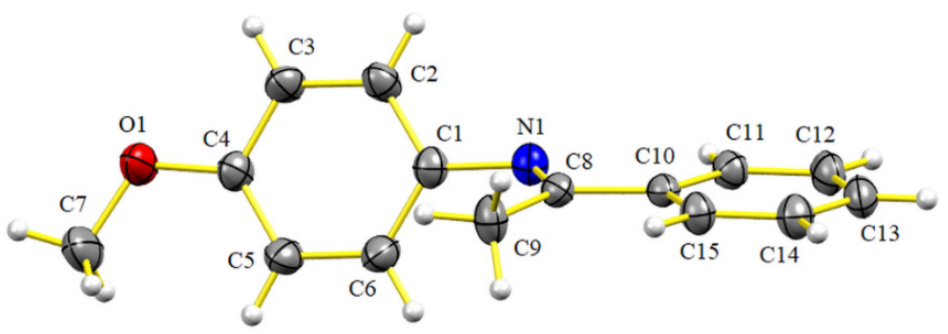

Figure 2. Structure of $\mathbf{5 i}$, as determined by single X-ray diffraction crystallography (ellipsoids at the $30 \%$ probability level).

2.2. One-Pot Synthesis of Indoles $\mathbf{6} \boldsymbol{a}-\boldsymbol{p}$ by Subsequent $\mathrm{Hg}(\mathrm{I})$ - and Pd(II)-Catalyzed Conversion of Anilines $1 a-g$ and $1 \mathbf{i}-\boldsymbol{k}$ with Alkynes $2 a-g$

The $\mathrm{Pd}(\mathrm{II})$-catalyzed conversion of imines/enamines into indoles has been performed by fairly similar methods [89-91], previously forming imine 5 or generating it in situ as the intermediate [66-68] (Scheme 1b). In all the approaches, the mechanism seems to start from the tautomerization of imine 5 to enamine 8 , which undergoes a dehydrogenative 
reaction by the metal to furnish the $\sigma-\mathrm{Pd}(\mathrm{II})$ complex 9 (Scheme 2). An aryl C-H activation affords palladacycle 10, bridging the aryl and the methylene moieties. By accomplishing the reductive elimination step, the internal oxidative cross-coupling reaction of $\mathbf{1 0}$ promotes the formation of the C-3/C-3a sigma bond of the corresponding indole 6 and $\operatorname{Pd}(0)$. The latter is oxidized back to $\mathrm{Pd}(\mathrm{II})$ by the oxidizing agent to renew the catalytic cycle. This aerobic oxidative cyclization reaction is only modestly efficient and regioselective in a onepot reaction beginning from the aniline and the ketone [67]. With an excess of $\mathrm{Cu}(\mathrm{OAc})_{2}$, on the other hand, the reaction produces a couple of indoles in moderate yields (41-55\%) [66].

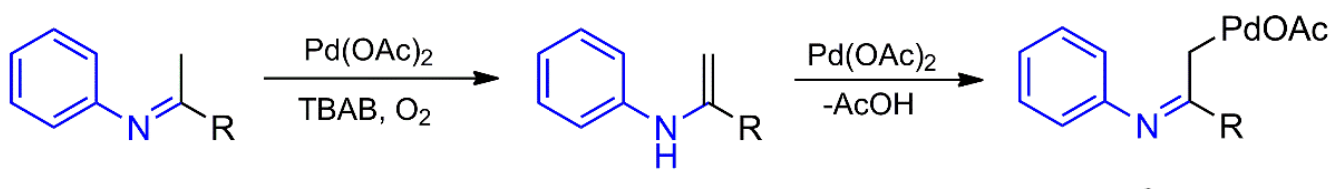

5

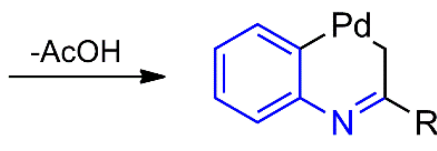

10
8

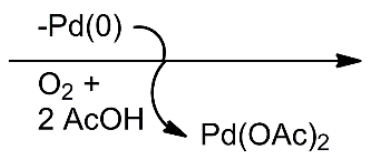

$\mathrm{Pd}(\mathrm{OAc})_{2}$

9<smiles>[R]c1cc2ccccc2[nH]1</smiles>

6

Scheme 2. Indole synthesis from imines through a Pd(II)-catalyzed oxidative cross-coupling.

Considering the feasibility of the oxidative cyclization reaction from imines $\mathbf{5}$ to indoles 6 , a one-pot reaction was explored that started from aniline $1 \mathbf{i}$ and phenylacetylene (2a) and progressed by a sequential $\mathrm{Hg}(\mathrm{I}) / \mathrm{Pd}$ (II)-catalyzed process. Diverse reagents were tested under aerobic conditions to find the proper oxidizing agent (Table 3). The reaction conditions were standardized and carried out in two steps. The first step consisted of applying the optimal reaction conditions found for the preparation of imines 5 , thus fixing the temperature and reaction time at $40{ }^{\circ} \mathrm{C}$ and $2 \mathrm{~h}$. The second step involved the addition of $\mathrm{Pd}(\mathrm{OAc})_{2}$ along with the oxidizing agent in $\mathrm{DMSO}$ as the solvent, and then stirring at $60{ }^{\circ} \mathrm{C}$ for $4.5 \mathrm{~h}$.

Table 3. Selection of the oxidizing agent and optimization of the reaction conditions for the one-pot conversion of $1 \mathbf{i}$ and $2 \mathbf{a}$ into indole $6 \mathbf{h}^{\mathrm{a}}$.

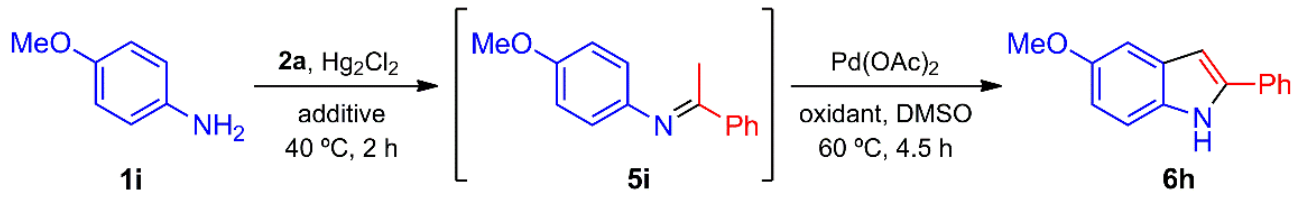

\begin{tabular}{|c|c|c|c|}
\hline Entry & Oxidant (mol equiv.) $^{b}$ & Additive (mol equiv.) & $5 \mathrm{i} / 6 \mathrm{~h}$ (Ratio) ${ }^{\mathrm{c}}(\text { Yield, } \%)^{\mathrm{d}}$ \\
\hline 1 & $\mathrm{Cu}(\mathrm{OAc})_{2}(3.0)$ & $\mathrm{Li}_{2} \mathrm{CO}_{3}(0.2)$ & $78: 22$ \\
\hline 2 & $\mathrm{O}_{2}$ & $\mathrm{Li}_{2} \mathrm{CO}_{3}(0.2)$ & $85: 15$ \\
\hline 3 & $\mathrm{Cu}(\mathrm{OAc})_{2} / \mathrm{O}_{2}(3.0)$ & $\mathrm{Li}_{2} \mathrm{CO}_{3}(0.2)$ & $46: 54$ \\
\hline 4 & $\mathrm{KMnO}_{4} / \mathrm{O}_{2}(3.0)$ & $\mathrm{Li}_{2} \mathrm{CO}_{3}(0.2)$ & $56: 44$ \\
\hline 5 & $\mathrm{NMMO} / \mathrm{O}_{2}(3.0)$ & $\mathrm{Li}_{2} \mathrm{CO}_{3}(0.2)$ & $67: 33$ \\
\hline 6 & $\mathrm{DTBP} / \mathrm{O}_{2}(3.0)$ & $\mathrm{Li}_{2} \mathrm{CO}_{3}(0.2)$ & $65: 35$ \\
\hline 7 & $\mathrm{Cu}(\mathrm{OTf})_{2} / \mathrm{O}_{2}(3.0)$ & $\mathrm{Li}_{2} \mathrm{CO}_{3}(0.2)$ & $100: 0$ \\
\hline 8 & $\mathrm{Cu}(\mathrm{OAc})_{2} / \mathrm{O}_{2}(1.0)$ & $\mathrm{Li}_{2} \mathrm{CO}_{3}(0.2)$ & $53: 47$ \\
\hline $9^{e}$ & $\mathrm{Cu}(\mathrm{OAc})_{2} / \mathrm{O}_{2}(3.0)$ & $\mathrm{Li}_{2} \mathrm{CO}_{3}(0.2)$ & $13: 87$ \\
\hline $10^{\mathrm{e}}$ & $\mathrm{Cu}(\mathrm{OAc})_{2} / \mathrm{O}_{2}(3.0)$ & $\mathrm{Li}_{2} \mathrm{CO}_{3}(0.2)$ & 6h (45) \\
\hline $11^{\mathrm{e}}$ & $\mathrm{Cu}(\mathrm{OAc})_{2} / \mathrm{O}_{2}(3.0)$ & - & 6h (50) \\
\hline $12^{\mathrm{e}, \mathrm{f}}$ & $\mathrm{Cu}(\mathrm{OAc})_{2} / \mathrm{O}_{2}(3.0)$ & $\mathrm{EtCO}_{2} \mathrm{H}(0.2)$ & 6h (46) \\
\hline $13^{e, f}$ & $\mathrm{Cu}(\mathrm{OAc})_{2}$ & $\mathrm{Li}_{2} \mathrm{CO}_{3}(0.2)$ & $6 \mathrm{~h}(52)$ \\
\hline $14^{\mathrm{e}}$ & $\mathrm{Cu}(\mathrm{OAc})_{2}(3.0)$ & - & $6 h(80)$ \\
\hline
\end{tabular}

a $1 \mathbf{i}$ (1.05 mol equiv.), 2a (1.0 mol equiv.), $\mathrm{Li}_{2} \mathrm{CO}_{3}$ (0.2 mol equiv.), $\mathrm{Hg}_{2} \mathrm{Cl}_{2}$ (0.05 mol equiv.), $\mathrm{Pd}(\mathrm{OAc}) 2$ (0.1 mol equiv.), and DMSO $(0.2 \mathrm{M}) .{ }^{\mathrm{b}}$ Oxygen gas was used. ${ }^{\mathrm{c}}$ Calculated by ${ }^{1} \mathrm{H}$ NMR of the reaction crude mixture. ${ }^{\mathrm{d}}$ After purification by column chromatography. ${ }^{\mathrm{e}} \mathrm{Pd}(\mathrm{OAc})_{2}(0.2 \mathrm{~mol}$ equiv. $)$ was employed. ${ }^{\mathrm{f}}$ The additive was added at the second step. $\mathrm{NMMO}=N$-methylmorpholine $N$-oxide, $\mathrm{DTBP}=$ di-tert-butyl peroxide. 
The synergic action of $\mathrm{Cu}(\mathrm{OAc})_{2}$ and oxygen turned out to be the best oxidizing agent (Table 3, entries 8 and 9), although no significant conversion was shown when reacting each separately (entries 1 and 2). The addition of 0.2 mol equivalents of $\mathrm{Pd}(\mathrm{OAc})_{2}$ was critical for improving the yield (entry 9). Interestingly, mixing all the catalysts with the oxidant and solvent (DMSO) under similar reaction conditions and as a single step did not provide any trace of the imine or the indole. A possible explanation is that the $\mathrm{Hg}(\mathrm{I})$ catalyst was inactivated by DMSO. Indeed, the first step was always inefficient with the use of this solvent (Table 1).

With the aim of optimizing the process, the additive was changed to $\mathrm{K}_{2} \mathrm{CO}_{3}$ and $\mathrm{Cs}_{2} \mathrm{CO}_{3}$ rather than $\mathrm{Li}_{2} \mathrm{CO}_{3}$, but without success (not shown in Table 3). Hence, the conversion depicted in Table 3 was carried out with or without the addition of $\mathrm{Li}_{2} \mathrm{CO}_{3}$ in the second step. The addition of an acid instead of $\mathrm{Li}_{2} \mathrm{CO}_{3}$ (entries 10-12) caused a non-significant decrease in the yield. A similar outcome was found without the presence of oxygen (entry 13). However, when both the additive and oxygen were removed from the whole process, the yield sharply increased (entry 14). The reaction temperatures and times with the best efficiency were determined, and the optimized method for the elaboration of $\mathbf{6 h}$ was applied to the entire series, mixing anilines $\mathbf{1 a}-\mathbf{g}$ and $\mathbf{1 i}-\mathbf{k}$ with acetylenes $\mathbf{2 a}-\mathbf{g}$, which gave the corresponding indoles $\mathbf{6 a}-\mathbf{p}$ (Scheme 3). Most of the 2-arylindoles were obtained in good yields, regardless of the position of the substituent in the benzene ring.

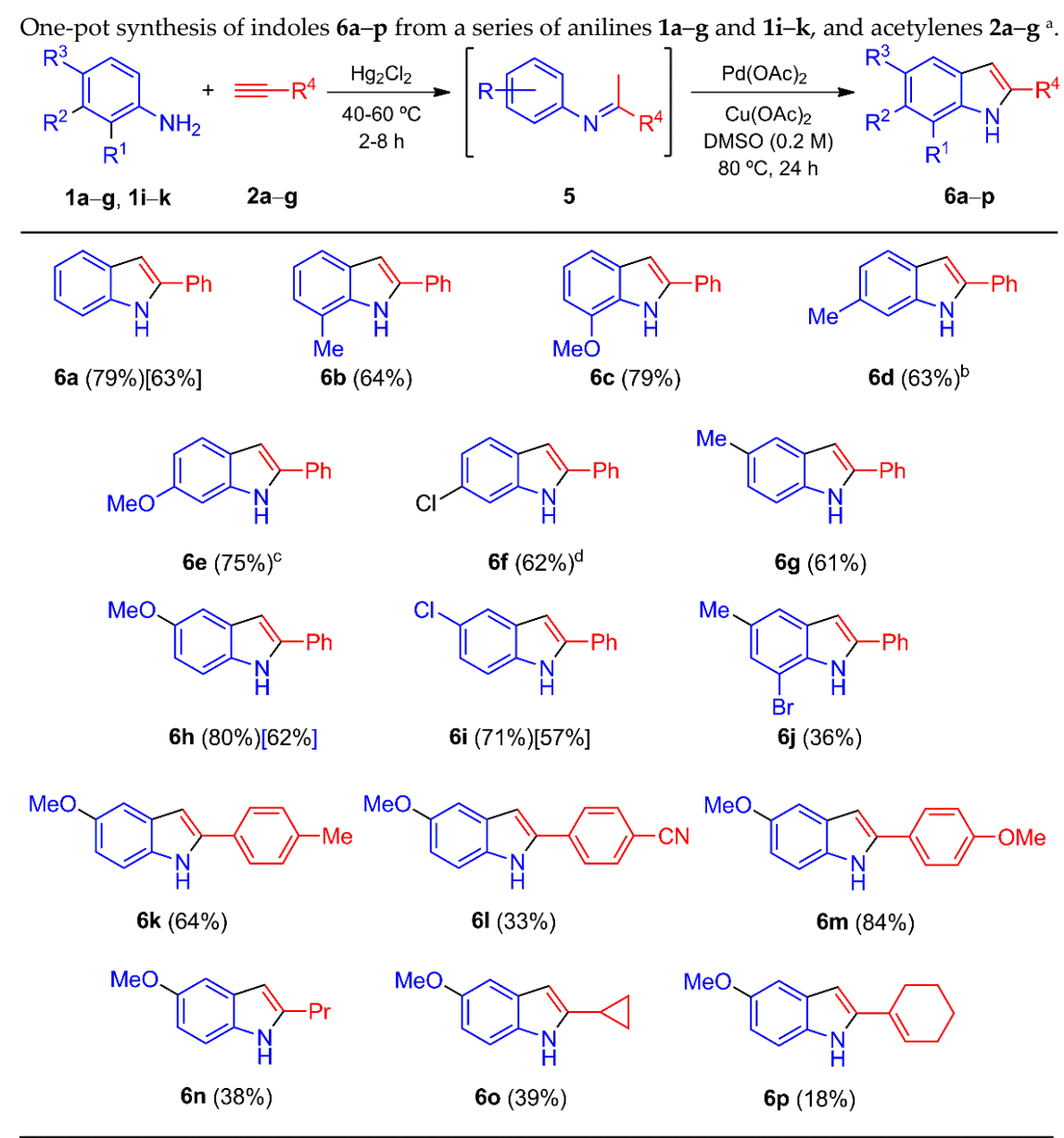

Scheme 3. ${ }^{\text {a }}$ Yields in square brackets were obtained by conversion of imines $\mathbf{5 a}$ and $\mathbf{5 i}-\mathbf{j}$ into indoles $\mathbf{6 a}$ and $\mathbf{6 h}-\mathbf{i}$ (see Experimental Section). ${ }^{\mathrm{b}}$ Minor isomer 4-methyl-2-phenyl- $1 H$-indole (6d') was detected (12\% ratio) by GC/MS of the crude mixture, but could not be isolated. ${ }^{\mathrm{c}}$ Minor isomer 4-methoxy-2-phenyl-1H-indole (6e') was detected (7\% ratio) by GC/MS of the crude mixture, but could not be isolated. ${ }^{d}$ Minor isomer 4-chloro-2-phenyl- $1 H$-indole $\left(\mathbf{6 f}^{\prime}\right)$ was detected (19\% ratio) by GC/MS of the crude mixture, but could not be isolated. 
On the other hand, the indoles produced in low yields showed a certain correlation with the imines afforded in fairly modest yields (Table 2). For example, the in-situ formation of imine $\mathbf{5 k}$ delivered indole $\mathbf{6} \mathbf{j}$ in a low yield. The unstable and non-isolated imines $5 \mathrm{~m}$ and $5 \mathbf{o}-\mathbf{q}$, generated by acetylenes $2 \mathrm{c}$ and $2 \mathbf{e}-\mathrm{g}$ respectively, provided low yields of their corresponding indoles $\mathbf{6} \mathbf{l}$ and $\mathbf{6 n}-\mathbf{p}$. It is likely that the low yield of indole $\mathbf{6} \mathbf{1}$ was due to the low stability of the imine under the two-step reaction conditions, since the corresponding $p$-cyanoacetophenone ( $7 \mathbf{b}$ ) was isolated in $20 \%$ yield. The reaction of aniline $1 \mathrm{~h}$ and phenylacetylene (2a) resulted in a complex mixture of products. With the use of meta-substituted anilines $\mathbf{1} \mathbf{d}-\mathbf{f}$ with $\mathbf{2 a}$, a mixture of regioisomers $\mathbf{6} \mathbf{d}-\mathbf{f} / \mathbf{6} \mathbf{d}^{\prime}-\mathbf{f}^{\prime}$ was found, respectively. The 6-substituted indoles $\mathbf{6} \mathbf{d}-\mathbf{f}$ were the major isomers, and the 4-substituted indoles $\mathbf{6} \mathbf{d}^{\prime}-\mathbf{f}^{\prime}$ the minor ones. The latter could not be isolated (see caption, Scheme 3).

Analogous second-step reaction conditions $\left(\mathrm{Pd}(\mathrm{OAc})_{2} / \mathrm{Cu}(\mathrm{OAc})_{2}\right.$, DMSO, $\left.80^{\circ} \mathrm{C}, 24 \mathrm{~h}\right)$ were evaluated for the preparation of indoles $6 \mathbf{a}$ and $\mathbf{6 h}-\mathbf{i}$ from imines $5 \mathbf{a}$ and $5 \mathbf{i}-\mathbf{j}$, leading to lower yields than those obtained from the one-pot procedure (Scheme 3, square brackets). This suggests that a possible $\mathrm{Hg} / \mathrm{Pd}$ transmetalation reaction during the one-pot process may foster the necessary catalytic activity to promote the oxidative cyclization of the in-situ formed imine and provide the indole. Actually, there are many examples of satisfactory palladium-catalyzed cross-coupling reactions involving a transmetalation process with organomercury substrates $[80,92,93]$.

The series of indoles $6 \mathbf{6}-\mathbf{p}$ was characterized by $\mathrm{IR},{ }^{1} \mathrm{H}$ and ${ }^{13} \mathrm{C}$ NMR (the signals were attributed by HMQC and HMBC experiments), and HRMS. Indoles $\mathbf{6 e}$ and $\mathbf{6 1}$ were isolated as colorless and pale reddish crystals respectively, and their structures were determined by single X-ray diffraction crystallography (Figure 3). Regarding 6e, the C-2-substituted benzene ring adopted a coplanar conformation in relation to the heterocycle (torsion angle: $\mathrm{N}(1)-\mathrm{C}(1)-\mathrm{C}(10)-\mathrm{C}(15)=1.8(3)$, see Supplementary Materials). A larger torsion angle can be appreciated for $\mathbf{6}$ (torsion angle: $\mathrm{C}(15)-\mathrm{C}(10)-\mathrm{C}(1)-\mathrm{N}(1)=32.41(18)$, see Supplementary Materials). Thus, it is likely that the $\pi$-system of the aromatic rings in $6 \mathbf{e}$ is stabilized by conjugation, despite the possible van der Waals repulsions triggered by the eclipsed conformation of the ortho $\mathrm{C}-\mathrm{H}$ protons $(\mathrm{C} 2-\mathrm{H}$ and $\mathrm{C} 11-\mathrm{H})$. Meanwhile, the coplanarity between the aromatic rings is lost for $\mathbf{6 1}$, leading to the rotation of the sigma bond C1-C10. This is probably due to the presence of the cyano group, which compensates for the loss of stability caused by the conjugation of the aromatic rings. The latter loss is due to the instability caused by such ortho $\mathrm{C}-\mathrm{H}$ and $\mathrm{N}-\mathrm{H}$ repulsions.

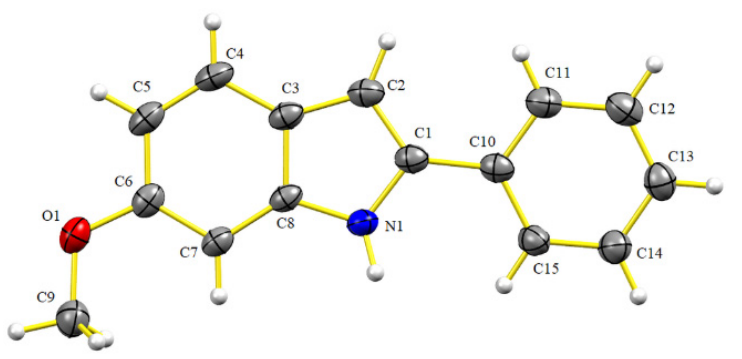

(a)

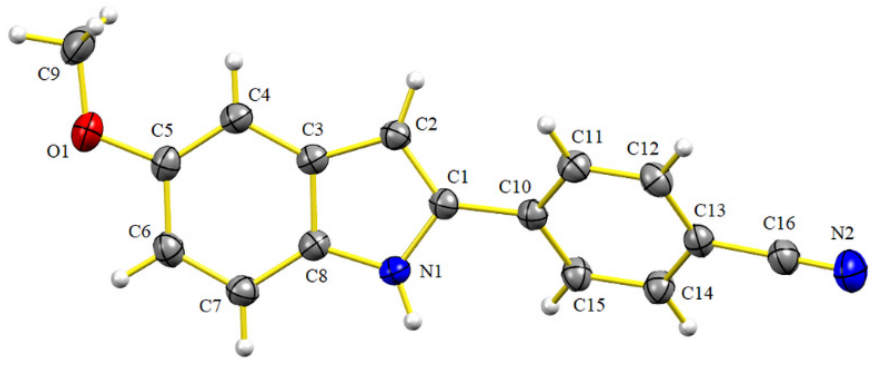

(b)

Figure 3. Structures of $\mathbf{6 e}(\mathbf{a})$ and $\mathbf{6 1}(\mathbf{b})$ as determined by single X-ray diffraction crystallography (ellipsoids at the $30 \%$ probability level).

\subsection{Mechanism of the Formation of Indoles $\mathbf{6} \boldsymbol{a}-\boldsymbol{p}$}

Taking into account the aforementioned results as well as the role played by the catalysts through each step [54,66-68] in the one-pot process for $\mathbf{2 a}$, two consecutive catalytic cycles can be suggested (Scheme 4). For the first event, the triple bond of 2a would be activated by a $\pi-H g(I)$ mercurinium cation complex I, and then probably stabilized by the formation of the alkynylmercury(I) II [83]. The addition of aniline $\mathbf{1}$ to either of the two possible complexes (I or II) would generate enamino-vinylmercury(I) III, followed by 
tautomerization to obtain imine IV. The protonolysis of the latter [80] would afford imine 5 along with the regeneration of catalyst $\mathrm{Hg}_{2} \mathrm{Cl}_{2}$ to initiate a new catalytic cycle.

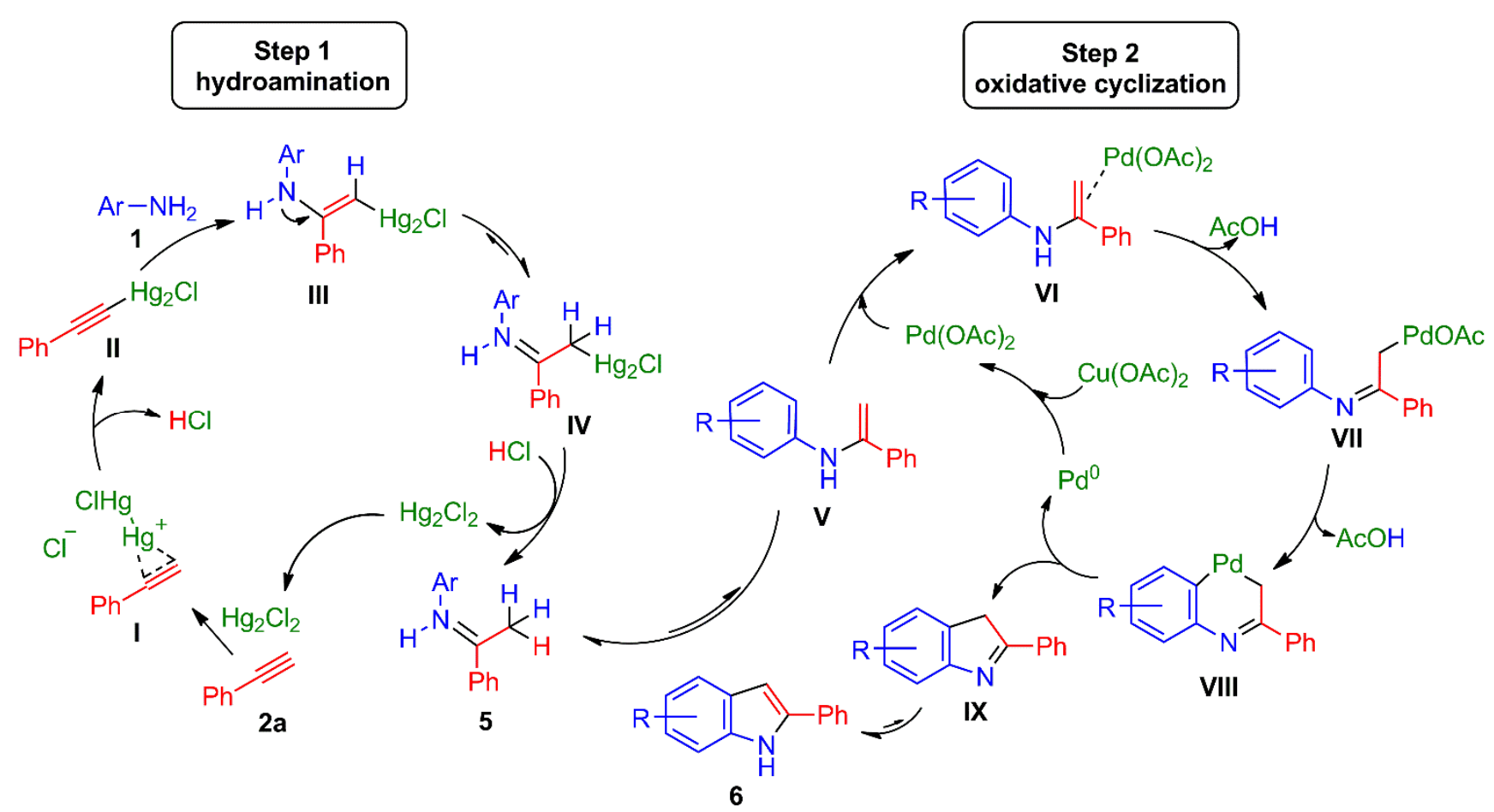

Scheme 4. Possible consecutive $\mathrm{Hg}(\mathrm{I}) / \mathrm{Pd}(\mathrm{II})$ catalytic cycles for the one-pot synthesis of indoles 6. Firstly, hydroamination provides imines 5 (Step 1), and then oxidative cyclization (Step 2) furnishes the indole frame.

The second step would start with the tautomerization of imine $\mathbf{5}$ to enamine $\mathbf{V}$, leading to the $\pi-\mathrm{Pd}(\mathrm{II})$ complex $\mathrm{VI}$ and the subsequent elimination of $\mathrm{AcOH}$ to deliver $\sigma$-Pd(II) complex VII (Scheme 4) [66-68]. Intramolecular aryl C-H activation would furnish palladacycle VIII, which would undergo a coupling reaction to give rise to the new C3-C3a sigma bond of heterocycle IX. The latter process would be associated with the reductive elimination of $\mathrm{Pd}(\mathrm{II})$ to form $\mathrm{Pd}(0)$, which would again be oxidized by the action of $\mathrm{Cu}(\mathrm{OAc})_{2}$. A final aromatization of IX would complete the synthesis of indoles 6 .

Considering the possibility that an $\mathrm{Hg} / \mathrm{Pd}$ transmetalation reaction takes place to improve the one-pot process with respect to the conversion of imines 5 to indoles 6 , a plausible alternative reaction mechanism can be postulated. The Pd(II)-catalyzed transmetalation reaction may occur either with the vinylmercurial complex III $[92,93]$ or the alkylmercurial complex IV to directly produce the $\sigma$-Pd(II) complex VII, which implies a shortcut capable of improving the process and avoiding the in-situ formation of imines $\mathbf{5}$.

Since modest efficiency of the mixture of the catalyst and oxidant agent $\mathrm{Pd}(\mathrm{OAc})_{2} /$ $\mathrm{Cu}(\mathrm{OAc})_{2}$ was achieved for the one-pot conversion of anilines and ketones to indoles in only two cases [66], the $\mathrm{Hg}(\mathrm{I})$-free reaction of aniline $1 \mathbf{i}$ with $2 \mathrm{a}$ in the presence of the $\mathrm{Pd}(\mathrm{OAc})_{2} / \mathrm{Cu}(\mathrm{OAc})_{2}$ couple was also tested. However, no indole was found [51]. Indeed, the alkyne was consumed only to generate 1,4-diphenylbuta-1,3-diyne, being the well-known, palladium-catalyzed, self-coupling product of terminal alkynes [94].

Given that $\mathrm{Hg}$ (II) was an active catalyst for promoting the formation of imine $5 \mathrm{i}$ (Table 1, entry 9), analogous alkynyl- and vinyl-mercury(II) (i.e., species I-III) could not be discarded as a competitive complex species [54]. Consequently, an assay was carried out with an $\mathrm{HgCl}_{2}$-catalyzed reaction of aniline $1 \mathbf{i}$ with $2 \mathbf{a}$, followed by the $\mathrm{Pd}(\mathrm{OAc})_{2} / \mathrm{Cu}(\mathrm{OAc})_{2}$ couple-catalyzed cyclization in $\mathrm{DMSO}$, which led to indole $\mathbf{6 h}$ in low yield $(12 \%)$. This indicates that the mechanism of the reaction described in Scheme 4 is mainly driven by $\mathrm{Hg}(\mathrm{I})$ intermediates (i.e., species I-IV). 


\section{Materials and Methods}

\subsection{General}

Melting points were determined on a Krüss KSP 1N (KRÜSS GmbH, Hamburg, Germany) capillary melting point apparatus. IR spectra were recorded on Perkin-Elmer 2000 (PerkinElmer, Waltham, MA, USA) and Bruker Vertex 70 (ATR-FT) (Bruker Corporation, Billerica, MA, USA) spectrophotometers. ${ }^{1} \mathrm{H}$ and ${ }^{13} \mathrm{C}$ NMR spectra were captured on Varian Mercury (300 MHz) (Varian, Inc., Palo Alto, CA, USA), Varian VNMR (500 MHz) (Varian, Inc., Palo Alto, CA, USA), and Bruker 600 AVANCE III (600 MHz) (Bruker Corporation, Billerica, MA, USA) instruments, with $\mathrm{CDCl}_{3}$ as the solvent and TMS as the internal standard. Signal assignments were based on 2D NMR spectra (HMQC, HMBC, and/or ROESY). Mass spectra (MS) were recorded on Thermo Polaris Q-Trace GC Ultra (Finnigan Co., Waltham, MA, USA) and Hewlett-Packard 5971 A (Hewlett Packard Co., Houston, TX, USA) spectrometers. High-resolution mass spectra (HRMS) were obtained (in electron impact mode) on a Jeol JSM-GCMateII (JEOL, Ltd., Tokyo, Japan) spectrometer. X-Ray crystallographic measurements were collected on an Oxford XcaliburS diffractometer (Rigaku Co., Tokyo, Japan). Analytical thin-layer chromatography was performed with 0.25 plates coated with E. Merck (Darmstadt, Germany) silica gel 60 F254 and visualized with a short/long-wavelength UV lamp. Flash column chromatography was conducted over Natland International Co. (Morrisville, NC, USA) silica gel (230-400 and 230-400 mesh). All air moisture-sensitive reactions were conducted under $\mathrm{N}_{2}$ in oven-dried glassware. DMSO was distilled over $\mathrm{CaH}_{2}$, and $\mathrm{Li}_{2} \mathrm{CO}_{3}$ and $\mathrm{K}_{2} \mathrm{CO}_{3}$ were dried overnight at $250{ }^{\circ} \mathrm{C}$ prior to use. All other reagents were utilized without further purification. Warning: The hazardous wastes of mercury-containing silica gel and reaction residues were treated with sulfur and placed in high-density plastic containers for disposal, then handled by an authorized hazardous waste company.

\subsection{General Method A for the Preparation of Imines $\mathbf{5} \boldsymbol{a}-\boldsymbol{n}$}

To a round-bottomed flask (at room temperature and in the dark), the corresponding arylacetylene $\mathbf{2 a}-\mathbf{d}$ (1.0 mol equiv.), $\mathrm{Li}_{2} \mathrm{CO}_{3}(0.20 \mathrm{~mol}$ equiv.), the respective aniline $\mathbf{1 a}-\mathbf{k}$ (1.05 mol equiv.), and mercury(I) chloride ( 0.05 mol equiv.) were successively added. The mixture was vigorously stirred at $60^{\circ} \mathrm{C}$ for $2-8 \mathrm{~h}$. The organic layer was extracted with EtOAc $(3 \times 5 \mathrm{~mL})$ and dried with $\mathrm{Na}_{2} \mathrm{SO}_{4}$. The solvent was removed under vacuum and the residue was purified by column chromatography over silica gel treated with $\mathrm{Et}_{3} \mathrm{~N}$ (10\% $\mathrm{w} / \mathrm{w})(40 \mathrm{~g} / \mathrm{g}$ crude, hexane/EtOAc, 98:2) to afford imines 5a-n.

\subsection{General Method B for the Preparation of Indoles $\mathbf{6} \boldsymbol{a}-\boldsymbol{p}$}

To a round-bottomed flask (at room temperature and in the dark), the corresponding alkyl and arylacetylenes $\mathbf{2 a - g}$ (1.0 mol equiv.), the respective aniline $\mathbf{1 a}-\mathbf{g}$ and $\mathbf{1 i}-\mathbf{k}(1.05 \mathrm{~mol}$ equiv.), and mercury(I) chloride ( 0.05 mol equiv.) were successively added. The mixture was vigorously stirred at $40-60^{\circ} \mathrm{C}$ for $2-8 \mathrm{~h}$, and anhydrous DMSO $(0.2 \mathrm{M}), \mathrm{Cu}(\mathrm{OAc})_{2}$ (1.5 mol equiv.), and $\mathrm{Pd}(\mathrm{OAc})_{2}(0.20$ mol equiv.) were successively added. The mixture was stirred at $80^{\circ} \mathrm{C}$ for $24 \mathrm{~h}$, filtered over celite, and washed with EtOAc $(4 \times 20 \mathrm{~mL})$. The organic layer was washed with brine $(40 \mathrm{~mL})$ and dried with $\mathrm{Na}_{2} \mathrm{SO}_{4}$. The solvent was removed under vacuum and the residue was purified by column chromatography over silica gel (30 g/g crude, hexane/EtOAc, 98:2) to provide indoles $\mathbf{6 a - p}$.

\subsection{General Method C for the Preparation of Indoles $\mathbf{6} \boldsymbol{a}$ and $\mathbf{6} \boldsymbol{h}-\boldsymbol{i}$ Starting from Imines $\mathbf{5} \boldsymbol{a}$ and $\mathbf{5} \boldsymbol{i}-\boldsymbol{j}$}

In a round-bottomed flask (at room temperature), the respective imine $5 \mathbf{a}$ and $5 \mathbf{i}-\mathbf{j}$, anhydrous $\mathrm{DMSO}(0.2 \mathrm{M}), \mathrm{Cu}(\mathrm{OAc})_{2}\left(1.5 \mathrm{~mol}\right.$ equiv.), and $\mathrm{Pd}(\mathrm{OAc})_{2}(0.20 \mathrm{~mol}$ equiv. $)$ were mixed and stirred at $80^{\circ} \mathrm{C}$ for $24 \mathrm{~h}$. The crude reaction was filtered over celite and washed with EtOAc $(4 \times 20 \mathrm{~mL})$. The organic layer was washed with brine $(40 \mathrm{~mL})$ and dried with $\mathrm{Na}_{2} \mathrm{SO}_{4}$. The solvent was removed under vacuum and the residue was purified by column 
chromatography over silica gel (50 g/g crude, hexane/EtOAc, 98:2) to obtain indoles 6a and $\mathbf{6 h}-\mathbf{i}$.

\subsection{Preparation and Characterization of Imines $\mathbf{5} \boldsymbol{a}-\boldsymbol{n}$}

\subsection{1. (E)-N-(1-Phenylethylidene)aniline (5a)}

Following general method $\mathrm{A}$, a mixture of $2 \mathrm{a}(0.094 \mathrm{~g}, 0.92 \mathrm{mmol}), \mathrm{Li}_{2} \mathrm{CO}_{3}(0.014 \mathrm{~g}$, $0.19 \mathrm{mmol}), 1 \mathrm{a}(0.090 \mathrm{~g}, 0.97 \mathrm{mmol})$, and $\mathrm{Hg}_{2} \mathrm{Cl}_{2}(0.022 \mathrm{~g}, 0.047 \mathrm{mmol})$ was reacted for $4 \mathrm{~h}$ to furnish $5 \mathbf{a}(0.159 \mathrm{~g}, 88 \%)$ as a yellow solid. $R f 0.72$ (hexane/EtOAc, $7: 3) ; \mathrm{mp} 35-36{ }^{\circ} \mathrm{C}$ (Lit. $37^{\circ} \mathrm{C}$ [10]; $42-43^{\circ} \mathrm{C}$ [95]). IR (film): $\bar{v} 3058,3027,1638,1593,1482,1447,1366,1287$, $1214,1072,1026,783,762,730,694 \mathrm{~cm}^{-1} .{ }^{1} \mathrm{H}$ NMR $\left(500 \mathrm{MHz}, \mathrm{CDCl}_{3}\right): \delta 2.23\left(\mathrm{~s}, 3 \mathrm{H}, \mathrm{CH}_{3}-2^{\prime}\right)$, 6.78-6.82 (m, 2H, H-2), 7.06-7.11 (m, 1H, H-4), 7.32-7.38 (m, 2H, H-3), 7.41-7.49 (m, 3H, H-3", H-4") , 7.95-7.80 (m, 2H, H-2"). ${ }^{13} \mathrm{C} \mathrm{NMR} \mathrm{(125} \mathrm{MHz,} \mathrm{CDCl} 3$ ): $\delta 17.4\left(\mathrm{CH}_{3}-2^{\prime}\right), 119.3$ (C-2), 123.2 (C-4), 127.1 (C-2"), 128.3 (C-3"), 128.9 (C-3), 130.4 (C-4"), 139.5 (C-1"), 151.7 (C-1), $165.4\left(\mathrm{C}-1^{\prime}\right)$. HRMS (EI): $m / z\left[\mathrm{M}^{+}\right]$calcd for $\mathrm{C}_{14} \mathrm{H}_{13} \mathrm{~N}$ : 195.1048; found: 195.1046.

\subsection{2. (E)-2-Methyl-N-(1-phenylethylidene)aniline (5b)}

Following general method $\mathrm{A}$, a mixture of $2 \mathrm{a}(0.101 \mathrm{~g}, 0.99 \mathrm{mmol}), \mathrm{Li}_{2} \mathrm{CO}_{3}(0.015 \mathrm{~g}$, $0.20 \mathrm{mmol}), \mathbf{1 b}(0.111 \mathrm{~g}, 1.04 \mathrm{mmol})$, and $\mathrm{Hg}_{2} \mathrm{Cl}_{2}(0.023 \mathrm{~g}, 0.049 \mathrm{mmol})$ was reacted for $4 \mathrm{~h}$ to give $5 \mathbf{b}(0.176 \mathrm{~g}, 85 \%)$ as a yellow solid. $\mathrm{Rf} 0.77$ (hexane/EtOAc, $7: 3$ ); mp $56-58{ }^{\circ} \mathrm{C}$ (Lit. $61^{\circ} \mathrm{C}$ [10]). IR (film): $\bar{v} 3063,3016,1637,1597,1578,1482,1447,1366,1287,1221,1114,1026$, 787, 765, 737, $692 \mathrm{~cm}^{-1}$. ${ }^{1} \mathrm{H}$ NMR $\left(600 \mathrm{MHz}, \mathrm{CDCl}_{3}\right): \delta 2.10$ (s, 3H, CH $\left.\mathrm{CH}_{3} \mathrm{Ar}\right), 2.16(\mathrm{~s}, 3 \mathrm{H}$, $\mathrm{CH}_{3}-2^{\prime}$ ), 6.65 (br d, $\left.J=7.8 \mathrm{~Hz}, 2 \mathrm{H}, \mathrm{H}-6\right), 7.00$ (br dd, $\left.J=7.8,7.2 \mathrm{~Hz}, 1 \mathrm{H}, \mathrm{H}-4\right), 7.17$ (br dd, $J=7.8,7.2 \mathrm{~Hz}, 1 \mathrm{H}, \mathrm{H}-5), 7.21$ (br d, $J=7.2 \mathrm{~Hz}, 1 \mathrm{H}, \mathrm{H}-3), 7.43-7.49$ (m, 3H, H-3", H-4"), 7.99-8.02 (m, 2H, H-2"). ${ }^{13} \mathrm{C}$ NMR (150 MHz, $\left.\mathrm{CDCl}_{3}\right)$ : $\delta 17.4\left(\mathrm{CH}_{3}-2^{\prime}\right), 17.8\left(\mathrm{CH}_{3} \mathrm{Ar}\right), 118.4$ (C-6), 123.2 (C-4), 126.3 (C-5), 127.1 (C-2, C-2"), 128.4 (C-3"), 130.3 (C-3), 130.4 (C-4"'), 139.4 $\left(\mathrm{C}-1^{\prime \prime}\right), 150.3(\mathrm{C}-1), 164.9\left(\mathrm{C}-1^{\prime}\right)$.

\subsection{3. (E)-2-Methoxy-N-(1-phenylethylidene)aniline (5c)}

Following general method $\mathrm{A}$, a mixture of $2 \mathrm{a}(0.107 \mathrm{~g}, 1.05 \mathrm{mmol}), \mathrm{Li}_{2} \mathrm{CO}_{3}(0.015 \mathrm{~g}$, $0.20 \mathrm{mmol}), 1 \mathrm{c}(0.135 \mathrm{~g}, 1.10 \mathrm{mmol})$, and $\mathrm{Hg}_{2} \mathrm{Cl}_{2}(0.025 \mathrm{~g}, 0.053 \mathrm{mmol})$ was reacted for $4 \mathrm{~h}$ to afford 5c (0.205 g, 87\%) as a yellow oil. $R f 0.70$ (hexane/EtOAc, 7:3). IR (film): $\bar{v} 3059$, 3001, 2957, 2834, 1684, 1635, 1590, 1489, 1448, 1366, 1242, 1208, 1180, 1115, 1046, 1026, 765, 746, $693 \mathrm{~cm}^{-1} .{ }^{1} \mathrm{H}$ NMR (500 MHz, $\left.\mathrm{CDCl}_{3}\right): \delta 2.18\left(\mathrm{~s}, 3 \mathrm{H}, \mathrm{CH}_{3}-2^{\prime}\right), 3.79\left(\mathrm{~s}, 3 \mathrm{H}, \mathrm{CH}_{3} \mathrm{O}\right), 6.78$ $(\mathrm{dd}, J=7.5,1.7 \mathrm{~Hz}, 2 \mathrm{H}, \mathrm{H}-6), 6.94(\mathrm{dd}, J=7.5,1.5 \mathrm{~Hz}, 1 \mathrm{H}, \mathrm{H}-3), 6.96(\mathrm{td}, J=7.5,1.5 \mathrm{~Hz}, 1 \mathrm{H}$, H-5), 7.08 (td, $J=7.5,1.7 \mathrm{~Hz}, 1 \mathrm{H}, \mathrm{H}-4), 7.42-7.48$ (m, 3H, H-3", $\left.\mathrm{H}-4{ }^{\prime \prime}\right), 7.97-8.03$ (m, 2H, $\left.\mathrm{H}-2^{\prime \prime}\right) .{ }^{13} \mathrm{C}$ NMR (125 MHz, $\left.\mathrm{CDCl}_{3}\right): \delta 17.8\left(\mathrm{CH}_{3}-2^{\prime}\right), 55.6\left(\mathrm{CH}_{3} \mathrm{O}\right), 111.5(\mathrm{C}-3), 120.5(\mathrm{C}-5)$, 120.8 (C-6), 124.1 (C-4), 127.3 (C-2"), 128.3 (C-3"), 130.4 (C-4"), 139.3 (C-1"), 140.5 (C-1), 148.9 (C-2), $167.1\left(\mathrm{C}-1^{\prime}\right)[96]$.

\subsection{4. (E)-3-Methyl-N-(1-phenylethylidene)aniline (5d)}

Following general method $\mathrm{A}$, a mixture of $2 \mathrm{a}(0.096 \mathrm{~g}, 0.94 \mathrm{mmol}), \mathrm{Li}_{2} \mathrm{CO}_{3}(0.014 \mathrm{~g}$, $0.19 \mathrm{mmol}), 1 \mathrm{~d}(0.106 \mathrm{~g}, 0.99 \mathrm{mmol})$, and $\mathrm{Hg}_{2} \mathrm{Cl}_{2}(0.022 \mathrm{~g}, 0.047 \mathrm{mmol})$ was reacted for $4 \mathrm{~h}$ to give $5 \mathbf{d}(0.163 \mathrm{~g}, 83 \%)$ as a yellow oil. $R f 0.67$ (hexane/EtOAc, 7:3); (Lit. mp $34{ }^{\circ} \mathrm{C}$ [10]). IR (film): $\bar{v} 3059,3001,2958,2834,1684,1634,1594,1485,1447,1367,1313,1288,1261$, $1193,1148,1045,913,852,784,765,694 \mathrm{~cm}^{-1} .{ }^{1} \mathrm{H} \mathrm{NMR}\left(500 \mathrm{MHz}, \mathrm{CDCl}_{3}\right): \delta 2.23(\mathrm{~s}, 3 \mathrm{H}$, $\left.\mathrm{CH}_{3}-2^{\prime}\right), 2.35$ (s, 3H, $\left.\mathrm{CH}_{3} \mathrm{Ar}\right), 6.60$ (dm, $\left.J=7.5 \mathrm{~Hz}, 1 \mathrm{H}, \mathrm{H}-6\right), 6.61-6.64(\mathrm{~m}, 1 \mathrm{H}, \mathrm{H}-2), 6.90$ (dm, $J=7.5 \mathrm{~Hz}, 1 \mathrm{H}, \mathrm{H}-4), 7.23$ (t, $J=7.5 \mathrm{~Hz}, 1 \mathrm{H}, \mathrm{H}-5), 7.41-7.48$ (m, 3H, H-3", H-4"), 7.94-7.98 (m, 2H, H-2"). ${ }^{13} \mathrm{C}$ NMR (125 MHz, $\left.\mathrm{CDCl}_{3}\right): \delta 17.3\left(\mathrm{CH}_{3}-2^{\prime}\right), 21.5\left(\mathrm{CH}_{3} \mathrm{Ar}\right), 116.3(\mathrm{C}-6)$, 120.0 (C-2), 123.9 (C-4), 127.1 (C-2"), 128.3 (C-3"), 128.8 (C-5), 130.4 (C-4"), 138.7 (C-3), 139.5 $\left(\mathrm{C}-1^{\prime \prime}\right), 151.7(\mathrm{C}-1), 165.2\left(\mathrm{C}-1^{\prime}\right)$. HRMS (EI): $m / z$ [M $\left.{ }^{+}\right]$calcd for $\mathrm{C}_{15} \mathrm{H}_{15} \mathrm{~N}$ : 209.1204; found: 209.1205 . 


\subsection{5. (E)-3-Methoxy-N-(1-phenylethylidene)aniline (5e)}

Following general method A, a mixture of $2 \mathbf{a}(0.096 \mathrm{~g}, 0.94 \mathrm{mmol}), \mathrm{Li}_{2} \mathrm{CO}_{3}(0.014 \mathrm{~g}$, $0.19 \mathrm{mmol}), 1 \mathrm{e}(0.122 \mathrm{~g}, 0.99 \mathrm{mmol})$, and $\mathrm{Hg}_{2} \mathrm{Cl}_{2}(0.022 \mathrm{~g}, 0.047 \mathrm{mmol})$ was reacted for $4 \mathrm{~h}$ to form $5 \mathbf{e}(0.178 \mathrm{~g}, 84 \%)$ as a yellow oil. Rf 0.70 (hexane/EtOAc, 7:3). IR (film): $\bar{v} 3452$, 3369, 2929, 2837, 1602, 1496, 1464, 1292, 1206, 1158, 1038, 835, 764, 688. ${ }^{1} \mathrm{H}$ NMR $(500 \mathrm{MHz}$, $\left.\mathrm{CDCl}_{3}\right): \delta 2.25\left(\mathrm{~s}, 3 \mathrm{H}, \mathrm{CH}_{3}-2^{\prime}\right), 3.81\left(\mathrm{~s}, 3 \mathrm{H}, \mathrm{CH}_{3} \mathrm{O}\right), 6.35-6.40(\mathrm{~m}, 2 \mathrm{H}, \mathrm{H}-2, \mathrm{H}-6), 6.64(\mathrm{ddd}$, $J=8.0,2.0,1.0 \mathrm{~Hz}, 1 \mathrm{H}, \mathrm{H}-4), 7.25$ ( $\mathrm{t}, J=8.0 \mathrm{~Hz}, 1 \mathrm{H}, \mathrm{H}-5), 7.42-7.49\left(\mathrm{~m}, 3 \mathrm{H}, \mathrm{H}-3{ }^{\prime \prime}, \mathrm{H}-4^{\prime \prime}\right)$, 7.95-7.98 (m, 2H, H-2" $).{ }^{13} \mathrm{C}$ NMR (125 MHz, $\left.\mathrm{CDCl}_{3}\right): \delta 17.4\left(\mathrm{CH}_{3}-2^{\prime}\right), 55.2\left(\mathrm{CH}_{3} \mathrm{O}\right), 105.0$ (C-2), 108.8 (C-4), 111.7 (C-6), 127.1 (C-2"), 128.3 (C-3"), 129.8 (C-5), 130.5 (C-4"), 139.4 (C-1"), 153.1 (C-1), 160.3 (C-3), $165.5\left(\mathrm{C}-1^{\prime}\right)$ [97].

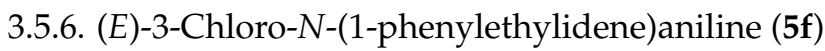

Following general method $\mathrm{A}$, a mixture of $2 \mathrm{a}(0.111 \mathrm{~g}, 1.09 \mathrm{mmol}), \mathrm{Li}_{2} \mathrm{CO}_{3}(0.016 \mathrm{~g}$, $0.22 \mathrm{mmol})$, 1f $(0.145 \mathrm{~g}, 1.14 \mathrm{mmol})$, and $\mathrm{Hg}_{2} \mathrm{Cl}_{2}(0.026 \mathrm{~g}, 0.055 \mathrm{mmol})$ was reacted for $4 \mathrm{~h}$ to provide $5 \mathrm{f}(0.132 \mathrm{~g}, 53 \%)$ as a brown oil. $R f 0.76$ (hexane/EtOAc, 7:3). IR (film): $\bar{v}$ 3060, 2920, 1635, 1588, 1470, 1448, 1367, 1288, 1212, 1072, 864, 788, 763, $692 \mathrm{~cm}^{-1} .{ }^{1} \mathrm{H}$ NMR $\left(600 \mathrm{MHz}, \mathrm{CDCl}_{3}\right): \delta 2.25\left(\mathrm{~s}, 3 \mathrm{H}, \mathrm{CH}_{3}-2^{\prime}\right), 6.68(\mathrm{dm}, J=8.1 \mathrm{~Hz}, 1 \mathrm{H}, \mathrm{H}-6), 6.81(\mathrm{t}, J=1.8 \mathrm{~Hz}$, $1 \mathrm{H}, \mathrm{H}-2), 7.07(\mathrm{dm}, J=8.1 \mathrm{~Hz}, 1 \mathrm{H}, \mathrm{H}-4), 7.27(\mathrm{t}, J=8.1 \mathrm{~Hz}, 1 \mathrm{H}, \mathrm{H}-5), 7.43-7.51(\mathrm{~m}, 3 \mathrm{H}, \mathrm{H}-3$ ", $\left.\mathrm{H}-4^{\prime \prime}\right), 7.94-7.97\left(\mathrm{~m}, 2 \mathrm{H}, \mathrm{H}-2^{\prime \prime}\right) .{ }^{13} \mathrm{C}$ NMR $\left(150 \mathrm{MHz}, \mathrm{CDCl}_{3}\right): \delta 17.9\left(\mathrm{CH}_{3}-2^{\prime}\right), 118.0(\mathrm{C}-6)$, 119.8 (C-2), 123.5 (C-4), 127.5 (C-2"), 128.7 (C-3"), 130.4 (C-5), 131.1 (C-4"), 134.8 (C-3), 139.3 (C-1"), $152.2(\mathrm{C}-1), 166.6\left(\mathrm{C}-1^{\prime}\right)$. HRMS (EI): $\mathrm{m} / z$ [M $\left.{ }^{+}\right]$calcd for $\mathrm{C}_{14} \mathrm{H}_{12} \mathrm{~N}$ : 229.0658; found: 209.0652 [13].

\subsection{7. (E)-4-Methyl-N-(1-phenylethylidene)aniline (5g)}

Following general method $\mathrm{A}$, a mixture of $2 \mathrm{a}(0.096,0.94 \mathrm{mmol}), \mathrm{Li}_{2} \mathrm{CO}_{3}(0.014 \mathrm{~g}$, $0.19 \mathrm{mmol}), 1 \mathrm{~g}(0.105 \mathrm{~g}, 0.98 \mathrm{mmol})$, and $\mathrm{Hg}_{2} \mathrm{Cl}_{2}(0.022 \mathrm{~g}, 0.047 \mathrm{mmol})$ was reacted for $2 \mathrm{~h}$ to afford $5 \mathbf{g}(0.179 \mathrm{~g}, 91 \%)$ as a yellow oil. $R f 0.76$ (hexane/EtOAc, 7:3); (Lit. $62{ }^{\circ} \mathrm{C}$ [10]). IR (film): $\bar{v} 3449,3363,3023,2920,1683,1633,1516,1505,1447,1364,1288,1266,1219,1026$, $842,827,763,692 \mathrm{~cm}^{-1} .{ }^{1} \mathrm{H}$ NMR $\left(600 \mathrm{MHz}, \mathrm{CDCl}_{3}\right): \delta 2.24\left(\mathrm{~s}, 3 \mathrm{H}, \mathrm{CH}_{3}-2^{\prime}\right), 2.35(\mathrm{~s}, 3 \mathrm{H}$, $\left.\mathrm{CH}_{3} \mathrm{Ar}\right), 6.70(\mathrm{~d}, J=7.8 \mathrm{~Hz}, 2 \mathrm{H}, \mathrm{H}-2), 7.16(\mathrm{~d}, J=7.8 \mathrm{~Hz}, 2 \mathrm{H}, \mathrm{H}-3), 7.41-7.49\left(\mathrm{~m}, 3 \mathrm{H}, \mathrm{H}-3{ }^{\prime \prime}\right.$, $\left.\mathrm{H}-4^{\prime \prime}\right), 7.94-7.99\left(\mathrm{~m}, 2 \mathrm{H}, \mathrm{H}-2^{\prime \prime}\right) .{ }^{13} \mathrm{C}$ NMR $\left(150 \mathrm{MHz}, \mathrm{CDCl}_{3}\right): \delta 17.3\left(\mathrm{CH}_{3}\right.$

-2'), $20.9\left(\mathrm{CH}_{3} \mathrm{Ar}\right), 119.4(\mathrm{C}-2), 127.1\left(\mathrm{C}-2^{\prime \prime}\right), 128.3\left(\mathrm{C}-3^{\prime \prime}\right), 129.5(\mathrm{C}-3), 130.3\left(\mathrm{C}-4^{\prime \prime}\right)$, 132.6 (C-4), 139.7 (C-1"), 149.0 (C-1), $165.5\left(\mathrm{C}-1^{\prime}\right)$. HRMS (EI): $\mathrm{m} / z$ [M $\left.\mathrm{M}^{+}\right]$calcd for $\mathrm{C}_{15} \mathrm{H}_{15} \mathrm{~N}$ : 209.1204; found: 209.1210 [51].

\subsection{8. (E)-4-(N,N-dimethylamino)- $N$-(1-phenylethylidene)aniline (5h)}

Following general method A, a mixture of $2 \mathbf{a}(0.099 \mathrm{~g}, 0.97 \mathrm{mmol}), \mathrm{Li}_{2} \mathrm{CO}_{3}(0.014 \mathrm{~g}$, $0.19 \mathrm{mmol}), 1 \mathrm{~h}(0.139 \mathrm{~g}, 1.02 \mathrm{mmol})$ and $\mathrm{Hg}_{2} \mathrm{Cl}_{2}(0.023 \mathrm{~g}, 0.049 \mathrm{mmol})$ was reacted for $2 \mathrm{~h}$ to obtain $5 \mathbf{h}(0.158 \mathrm{~g}, 68 \%)$ as a brown solid. $R f 0.53$ (hexane/EtOAc, 7:3); mp $90-92{ }^{\circ} \mathrm{C}$. IR (film): $\bar{v}$ 2918, 2803, 1622, 1510, 1446, 1364, 1222, 830, 760, $690 \mathrm{~cm}^{-1} .{ }^{1} \mathrm{H}$ NMR $(500 \mathrm{MHz}$, $\left.\mathrm{CDCl}_{3}\right): \delta 2.28\left(\mathrm{~s}, 3 \mathrm{H}, \mathrm{CH}_{3}-2^{\prime}\right), 2.95\left(\mathrm{~s}, 6 \mathrm{H},\left(\mathrm{CH}_{3}\right)_{2} \mathrm{~N}\right), 6.75-6.82(\mathrm{~m}, 4 \mathrm{H}, \mathrm{H}-2, \mathrm{H}-3), 7.41-7.45$ $\left(\mathrm{m}, 3 \mathrm{H}, \mathrm{H}-3 ", \mathrm{H} 4{ }^{\prime \prime}\right), 7.95-7.97\left(\mathrm{~m}, 2 \mathrm{H}, \mathrm{H}-2^{\prime \prime}\right) .{ }^{13} \mathrm{C} \mathrm{NMR}\left(125 \mathrm{MHz}, \mathrm{CDCl}_{3}\right): \delta 17.3\left(\mathrm{CH}_{3}-2^{\prime}\right)$, $41.2\left(\left(\mathrm{CH}_{3}\right)_{2} \mathrm{~N}\right), 113.5(\mathrm{C}-3), 121.0(\mathrm{C}-2), 127.0\left(\mathrm{C}-2^{\prime \prime}\right), 128.3\left(\mathrm{C}-3^{\prime \prime}\right), 130.1\left(\mathrm{C}-4^{\prime \prime}\right), 140.1\left(\mathrm{C}-1^{\prime \prime}\right)$, 141.7 (C-1), 147.4 (C-4), 165.0 (C-1'). HRMS (EI): $m / z$ [M $\left.\mathrm{M}^{+}\right]$calcd for $\mathrm{C}_{16} \mathrm{H}_{18} \mathrm{~N}_{2}$ : 238.1470; found: 238.1471 [98].

\subsection{9. (E)-4-Methoxy-N-(1-phenylethylidene)aniline (5i)}

Following general method A, a mixture of $2 \mathrm{a}(0.125 \mathrm{~g}, 1.23 \mathrm{mmol}), \mathrm{Li}_{2} \mathrm{CO}_{3}(0.018 \mathrm{~g}$, $0.24 \mathrm{mmol}), 1 \mathrm{i}(0.158 \mathrm{~g}, 1.28 \mathrm{mmol})$, and $\mathrm{Hg}_{2} \mathrm{Cl}_{2}(0.029 \mathrm{~g}, 0.06 \mathrm{mmol})$ was reacted for $2 \mathrm{~h}$ to furnish $5 \mathbf{i}(0.252 \mathrm{~g}, 91 \%)$ as a pale yellow crystalline solid. $R f$ 0.70 (hexane/EtOAc, 7:3); $\mathrm{mp}$ 93-94 ${ }^{\circ} \mathrm{C}$ (Lit. $86^{\circ} \mathrm{C}$ [10,95]; Lit. 85-86 ${ }^{\circ} \mathrm{C}$ [50]). IR (KBr): v 2954, 2929, 1616, 1576, 1510, $1443,1365,1284,1240,1210,1032,846,771,752,699 \mathrm{~cm}^{-1} .{ }^{1} \mathrm{H}$ NMR $\left(600 \mathrm{MHz}, \mathrm{CDCl}_{3}\right)$ : $\delta 2.26\left(\mathrm{~s}, 3 \mathrm{H}, \mathrm{CH}_{3}-2^{\prime}\right), 3.82\left(\mathrm{~s}, 3 \mathrm{H}, \mathrm{CH}_{3} \mathrm{O}\right), 6.73-6.79(\mathrm{~m}, 2 \mathrm{H}, \mathrm{H}-2), 6.89-6.94(\mathrm{~m}, 2 \mathrm{H}, \mathrm{H}-3)$, 7.41-7.49 (m, 3H, H-3", H-4"), 7.95-7.98 (m, 2H, H-2"). ${ }^{13} \mathrm{C}$ NMR (150 MHz, $\left.\mathrm{CDCl}_{3}\right): \delta$ 
17.3 (C-2'), $55.5\left(\mathrm{CH}_{3} \mathrm{O}\right), 114.2$ (C-3), 120.7 (C-2), 127.1 (C-2"), 128.3 (C-3"), 130.3 (C-4"), 139.8 (C-1"), 144.8 (C-1), 155.9 (C-4), $165.7\left(\mathrm{C}-1^{\prime}\right)$. HRMS (EI): $\mathrm{m} / z$ [ $\left[\mathrm{M}^{+}\right]$calcd for $\mathrm{C}_{15} \mathrm{H}_{15} \mathrm{NO}$ : 225.1154; found: 225.1164 [51,99].

\subsubsection{0. (E)-4-Chloro-N-(1-phenylethylidene)aniline (5j)}

Following general method A, a mixture of $2 \mathrm{a}(0.119 \mathrm{~g}, 1.17 \mathrm{mmol}), \mathrm{Li}_{2} \mathrm{CO}_{3}(0.017 \mathrm{~g}$, $0.23 \mathrm{mmol}), \mathbf{1 j}(0.155 \mathrm{~g}, 1.22 \mathrm{mmol})$, and $\mathrm{Hg}_{2} \mathrm{Cl}_{2}(0.027 \mathrm{~g}, 0.057 \mathrm{mmol})$ was reacted for $2 \mathrm{~h}$ to give $5 \mathbf{j}\left(0.209 \mathrm{~g}, 78 \%\right.$ ) as a yellow solid. $R f 0.76$ (hexane/EtOAc, 7:3); $\mathrm{mp} 68-70{ }^{\circ} \mathrm{C}$ (Lit. 73-74 ${ }^{\circ} \mathrm{C}$ [99]). IR (film): $\bar{v} 3061,2955,2854,1634,1579,1483,1447,1367,1288,1214,1091$, $1010,844,762,692,674 \mathrm{~cm}^{-1} .{ }^{1} \mathrm{H}$ NMR $\left(500 \mathrm{MHz}, \mathrm{CDCl}_{3}\right): \delta 2.23\left(\mathrm{~s}, 3 \mathrm{H}, \mathrm{CH}_{3}-2^{\prime}\right), 6.71-6.76$ (m, 2H, H-2), 7.28-7.33 (m, 2H, H-3), 7.42-7.50 (m, 3H, H-3", H-4"), 7.93-7.98 (m, 2H, H-2"). ${ }^{13} \mathrm{C}$ NMR (125 MHz, $\left.\mathrm{CDCl}_{3}\right): \delta 17.4\left(\mathrm{CH}_{3}-2^{\prime}\right), 120.8(\mathrm{C}-2), 127.2\left(\mathrm{C}-2^{\prime \prime}\right), 128.4(\mathrm{C}-3$ "), 128.5 (C-4), 129.0 (C-3), 130.7 (C-4"), 139.2 (C-1"), 150.2 (C-1), 166.2 (C-1') [13,51].

\subsubsection{1. (E)-2-Bromo-4-methoxy- $N$-(1-phenylethylidene)aniline (5k)}

Following general method $\mathrm{A}$, a mixture of $2 \mathbf{a}(0.093 \mathrm{~g}, 0.91 \mathrm{mmol}), \mathrm{Li}_{2} \mathrm{CO}_{3}(0.013 \mathrm{~g}$, $0.182 \mathrm{mmol}), 1 \mathrm{k}(0.177 \mathrm{~g}, 0.95 \mathrm{mmol})$, and $\mathrm{Hg}_{2} \mathrm{Cl}_{2}(0.021 \mathrm{~g}, 0.044 \mathrm{mmol})$ was reacted for $8 \mathrm{~h}$ to produce $5 \mathbf{k}(0.110 \mathrm{~g}, 42 \%)$ as a yellow oil. $R f 0.73$ (hexane/EtOAc, 7:3). IR (film): $\bar{v} 3057$, 3026, 2921, 1645, 1634, 1578, 1480, 1447, 1366, 1293, 1221, 1044, 865, 828, 761, $692 \mathrm{~cm}^{-1} .{ }^{1} \mathrm{H}$ $\operatorname{NMR}\left(500 \mathrm{MHz}, \mathrm{CDCl}_{3}\right): \delta 2.19\left(\mathrm{~s}, 3 \mathrm{H}, \mathrm{CH}_{3}-2^{\prime}\right), 2.33\left(\mathrm{~s}, 3 \mathrm{H}, \mathrm{CH}_{3} \mathrm{Ar}\right), 6.68(\mathrm{~d}, J=8.0 \mathrm{~Hz}, 1 \mathrm{H}$, H-6), 7.09 (dd, J = 8.0, 2.0 Hz, 1H, H-5), 6.43 (d, $J=2.0 \mathrm{~Hz}, 1 \mathrm{H}, \mathrm{H}-3), 7.44-7.50$ (m, 3H, H-3", $\left.\mathrm{H}-4^{\prime \prime}\right), 7.98-8.02\left(\mathrm{~m}, 2 \mathrm{H}, \mathrm{H}-2^{\prime}\right) .{ }^{13} \mathrm{C}$ NMR $\left(125 \mathrm{MHz}, \mathrm{CDCl}_{3}\right): \delta 18.0\left(\mathrm{CH}_{3}-2^{\prime}\right), 20.5\left(\mathrm{CH}_{3} \mathrm{Ar}\right)$, 113.5 (C-2), 120.1 (C-6), 127.4 (C-2"), 128.4 (C-3"), 128.7 (C-5), 130.7 (C-4"), 133.1 (C-3), 134.2 (C-4), 139.1 (C-1"), $147.4(\mathrm{C}-1), 167.6$ (C-1'). HRMS (EI): $m / z$ [M $\left.\mathrm{M}^{+}\right]$calcd for $\mathrm{C}_{15} \mathrm{H}_{14} \mathrm{BrN}$ : 287.0310; found: 287.0318.

\subsubsection{2. (E)-4-Methoxy-N-(1-(p-tolyl)ethylidene)aniline (51)}

Following general method $\mathrm{A}$, a mixture of $\mathbf{2 b}(0.118 \mathrm{~g}, 1.02 \mathrm{mmol}), \mathrm{Li}_{2} \mathrm{CO}_{3}(0.015 \mathrm{~g}$, $0.20 \mathrm{mmol}), \mathbf{1 i}(0.132 \mathrm{~g}, 1.07 \mathrm{mmol})$, and $\mathrm{Hg}_{2} \mathrm{Cl}_{2}(0.024 \mathrm{~g}, 0.051 \mathrm{mmol})$ was reacted for $2 \mathrm{~h}$ to generate $51(0.221 \mathrm{~g}, 91 \%)$ as a yellow solid. $R f 0.73$ (hexane/EtOAc, 7:3); $\mathrm{mp} 78-80{ }^{\circ} \mathrm{C}$ (Lit. $83^{\circ} \mathrm{C}$ [10]). IR (film): $\bar{v} 2996,2954,2930,2835,1621,1576,1505,1445,1366,1286,1242,1211$, $1181,1032,846,761,699 \mathrm{~cm}^{-1} .{ }^{1} \mathrm{H}$ NMR $\left(500 \mathrm{MHz}, \mathrm{CDCl}_{3}\right): \delta 2.22\left(\mathrm{~s}, 3 \mathrm{H}, \mathrm{CH}_{3}-2^{\prime}\right), 2.40(\mathrm{~s}$, $\left.3 \mathrm{H}, \mathrm{CH}_{3} \mathrm{Ar}\right), 3.81\left(\mathrm{~s}, 3 \mathrm{H}, \mathrm{CH}_{3} \mathrm{O}\right), 6.72-6.76(\mathrm{~m}, 2 \mathrm{H}, \mathrm{H}-2), 6.88-6.92(\mathrm{~m}, 2 \mathrm{H}, \mathrm{H}-3), 7.22-7.25$ (m, 2H, H-3"), 7.84-7.87 (m, 2H, H-2" ). ${ }^{13} \mathrm{C}$ NMR (125 MHz, CDCl $): \delta 17.2\left(\mathrm{CH}_{3}-2^{\prime}\right), 21.3$ $\left(\mathrm{CH}_{3} \mathrm{Ar}\right), 55.5\left(\mathrm{CH}_{3} \mathrm{O}\right), 114.2(\mathrm{C}-3), 120.8(\mathrm{C}-2), 127.1\left(\mathrm{C}-2^{\prime \prime}\right), 129.0\left(\mathrm{C}-3{ }^{\prime \prime}\right), 137.1\left(\mathrm{C}-1^{\prime \prime}\right), 140.5$ (C-4"), 145.0 (C-1), 155.8 (C-4), 165.5 (C-1') [100].

\subsubsection{3. (E)-4-(1-((4-methoxyphenyl)imino)ethyl)benzonitrile (5m)}

Following general method A, a mixture of $2 \mathrm{c}(0.083 \mathrm{~g}, 0.65 \mathrm{mmol}), \mathrm{Li}_{2} \mathrm{CO}_{3}(0.010 \mathrm{~g}$, $0.13 \mathrm{mmol}), 1 \mathrm{i}(0.084 \mathrm{~g}, 0.68 \mathrm{mmol})$, and $\mathrm{Hg}_{2} \mathrm{Cl}_{2}(0.014 \mathrm{~g}, 0.03 \mathrm{mmol})$ was reacted for $2 \mathrm{~h}$, resulting in an inseparable mixture of $5 \mathrm{~m} / 7 \mathbf{b}$ (95:5) as an instable brown solid. The yield of compound $5 \mathrm{~m}(0.147 \mathrm{~g}, 90 \%)$ was estimated by ${ }^{1} \mathrm{H}$ NMR and GC/MS. Rf 0.48 (hexano/AcOEt, 7:3). ${ }^{1} \mathrm{H} \mathrm{NMR}\left(500 \mathrm{MHz}, \mathrm{CDCl}_{3}\right): \delta 2.28\left(\mathrm{~s}, 3 \mathrm{H}, \mathrm{CH}_{3}-2^{\prime}\right), 3.83\left(\mathrm{~s}, 3 \mathrm{H}, \mathrm{CH}_{3} \mathrm{O}\right)$, 6.73-6.78 (m, 2H, H-2), 6.91-6.95 (m, 2H, H-3), 7.72-7.75 (m, 2H, H-3"), 8.04-8.09 (m, 2H, H-2"). Signals attributed to $7 \mathrm{~b}: 2.65\left(\mathrm{~s}, \mathrm{CH}_{3}-2^{\prime}\right), 3.74\left(\mathrm{~s}, \mathrm{CH}_{3} \mathrm{O}\right), 7.74-7.80(\mathrm{~m}, \mathrm{H}-3$ ") [100].

\subsubsection{4. (E)-4-Methoxy-N-(1-(4-methoxyphenyl)ethylidene)aniline (5n)}

Following general method $\mathrm{A}$, a mixture of $\mathbf{2 d}(0.095 \mathrm{~g}, 0.72 \mathrm{mmol}), \mathrm{Li}_{2} \mathrm{CO}_{3}(0.011 \mathrm{~g}$, $0.15 \mathrm{mmol}), \mathbf{1 i}(0.093 \mathrm{~g}, 0.76 \mathrm{mmol})$, and $\mathrm{Hg}_{2} \mathrm{Cl}_{2}(0.017 \mathrm{~g}, 0.036 \mathrm{mmol})$ was reacted for $2 \mathrm{~h}$ to form $5 \mathbf{n}(0.152 \mathrm{~g}, 83 \%)$ as a pale yellow solid. $R f 0.57$ (hexane/EtOAc, 7:3); mp 130-132 ${ }^{\circ} \mathrm{C}$ (Lit. $132-134{ }^{\circ} \mathrm{C}$ [95]). IR (film): v 2968, 2837, 1626, 1601, 1502, 1379, 1286, 1258, 1239, $1207,1172,1028,833 \mathrm{~cm}^{-1} .{ }^{1} \mathrm{H}$ NMR $\left(600 \mathrm{MHz}, \mathrm{CDCl}_{3}\right): \delta 2.22\left(\mathrm{~s}, 3 \mathrm{H}, \mathrm{CH}_{3}-2^{\prime}\right), 3.82(\mathrm{~s}, 3 \mathrm{H}$, $\left.\mathrm{CH}_{3} \mathrm{O}-4\right), 3.86$ (s, 3H, $\mathrm{CH}_{3} \mathrm{O}-4$ ") $)$ 6.72-6.76 (m, 2H, H-2), 6.88-6.92 (m, 2H, H-3), 6.93-6.96 (m, 2H, H-3"), 7.91-7.95 (m, 2H, H-2"). ${ }^{13} \mathrm{C}$ NMR (150 MHz, $\left.\mathrm{CDCl}_{3}\right): \delta 17.1\left(\mathrm{C}-2^{\prime}\right), 55.4$ 
$\left(\mathrm{CH}_{3} \mathrm{O}-\mathrm{C} 4{ }^{\prime \prime}\right), 55.5\left(\mathrm{CH}_{3} \mathrm{O}-\mathrm{C} 4\right), 113.6$ (C-3"), $114.2(\mathrm{C}-3), 120.9$ (C-2), 128.7 (C-2"), 132.5 (C-1"), 145.0 (C-1), 155.8 (C-4), 161.4 (C4"), 164.8 (C-1') [99,100].

3.6. Preparation and Characterization of Indoles $\mathbf{6} \boldsymbol{a}-\boldsymbol{p}$

3.6.1. 2-Phenyl-1H-indole (6a)

Following general method B, a mixture of $2 \mathbf{a}(0.080 \mathrm{~g}, 0.79 \mathrm{mmol}), \mathbf{1 a}(0.077 \mathrm{~g}$, $0.83 \mathrm{mmol})$, and $\mathrm{Hg}_{2} \mathrm{Cl}_{2}(0.019 \mathrm{~g}, 0.04 \mathrm{mmol})$ was stirred at $60{ }^{\circ} \mathrm{C}$ for $4 \mathrm{~h}$. It was then reacted with DMSO $(3.9 \mathrm{~mL}), \mathrm{Cu}(\mathrm{OAc})_{2}(0.215 \mathrm{~g}, 1.18 \mathrm{mmol})$, and $\mathrm{Pd}(\mathrm{OAc})_{2}(0.035 \mathrm{~g}$, $0.16 \mathrm{mmol}$ ) to yield $\mathbf{6 a}(0.120 \mathrm{~g}, 79 \%)$ as a brown solid. $R f 0.77$ (hexane/EtOAc, 7:3).

Following general method $\mathrm{C}$, a mixture of $5 \mathrm{a}(0.088 \mathrm{~g}, 0.45 \mathrm{mmol})$, DMSO $(2.2 \mathrm{~mL})$, $\mathrm{Cu}(\mathrm{OAc})_{2}(0.123 \mathrm{~g}, 0.68 \mathrm{mmol})$, and $\mathrm{Pd}(\mathrm{OAc})_{2}(0.020 \mathrm{~g}, 0.09 \mathrm{mmol})$ was reacted to yield $6 \mathbf{a}$ $(0.054 \mathrm{~g}, 63 \%)$ as a pale brownish solid. $R f 0.77$ (hexane/EtOAc, 7:3); mp 189-190 ${ }^{\circ} \mathrm{C}$ (Lit. 189-190 ${ }^{\circ} \mathrm{C}$ [66], $188-189^{\circ} \mathrm{C}$ [101], $187-188^{\circ} \mathrm{C}$ [102]). IR (ATR): $\bar{v} 3439,2919,2853,1455$,

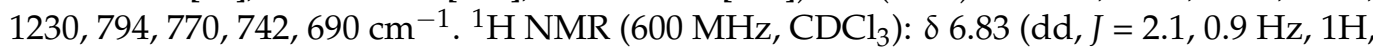
$\mathrm{H}-3), 7.12(\mathrm{td}, J=7.8,0.6 \mathrm{~Hz}, 1 \mathrm{H}, \mathrm{H}-5), 7.19(\mathrm{td}, J=7.8,1.2 \mathrm{~Hz}, 1 \mathrm{H}, \mathrm{H}-6), 7.30-7.33(\mathrm{~m}, 1 \mathrm{H}$, H-4'), 7.39 (dd, $J=7.8,0.9$ Hz, 1H, H-7), 7.41-7.46 (m, 2H, H-3'), 7.63 (dd, $J=7.8,0.9 \mathrm{~Hz}$, $1 \mathrm{H}, \mathrm{H}-4), 7.64-7.67\left(\mathrm{~m}, 2 \mathrm{H}, \mathrm{H}-2^{\prime}\right), 8.32(\mathrm{br} \mathrm{s}, 1 \mathrm{H}, \mathrm{NH}) .{ }^{13} \mathrm{C} \mathrm{NMR}\left(150 \mathrm{MHz}, \mathrm{CDCl}_{3}\right): \delta 100.0$ (C-3), 110.9 (C-7), 120.3 (C-5), 120.7 (C-4), 122.4 (C-6), 125.2 (C-2'), 127.7 (C-4'), 129.0 (C-3'), 129.3 (C-3a), $132.4\left(\mathrm{C}-1^{\prime}\right), 136.8$ (C-7a), 137.9 (C-2).

\subsubsection{7-Methyl-2-phenyl-1H-indole (6b)}

Following general method B, a mixture of $2 \mathbf{a}(0.077 \mathrm{~g}, 0.57 \mathrm{mmol}), \mathbf{1 b}(0.085 \mathrm{~g}$, $0.79 \mathrm{mmol})$, and $\mathrm{Hg}_{2} \mathrm{Cl}_{2}(0.018 \mathrm{~g}, 0.04 \mathrm{mmol})$ was stirred at $60{ }^{\circ} \mathrm{C}$ for $4 \mathrm{~h}$. It was then reacted with DMSO $(3.8 \mathrm{~mL}), \mathrm{Cu}(\mathrm{OAc})_{2}(0.205 \mathrm{~g}, 1.13 \mathrm{mmol})$, and $\mathrm{Pd}(\mathrm{OAc})_{2}(0.034 \mathrm{~g}$, $0.15 \mathrm{mmol}$ ) to provide $6 \mathrm{~b}(0.10 \mathrm{~g}, 64 \%)$ as a brown solid. $R f 0.67$ (hexane/EtOAc, 7:3); mp 114-116 ${ }^{\circ} \mathrm{C}$ (Lit. $112-118^{\circ} \mathrm{C}$ [103]). IR (ATR): $\bar{v} 3450,1601,1486,1449,1335,1330,1299,804$, 770, 737, $690 \mathrm{~cm}^{-1} .{ }^{1} \mathrm{H}$ NMR $\left(500 \mathrm{MHz}, \mathrm{CDCl}_{3}\right): \delta 2.52\left(\mathrm{~s}, 3 \mathrm{H}, \mathrm{CH}_{3} \mathrm{Ar}\right), 6.81(\mathrm{~d}, J=2.5 \mathrm{~Hz}$, $1 \mathrm{H}, \mathrm{H}-3), 6.98(\mathrm{dm}, J=7.5 \mathrm{~Hz}, 1 \mathrm{H}, \mathrm{H}-6), 7.04(\mathrm{t}, J=7.5 \mathrm{~Hz}, 1 \mathrm{H}, \mathrm{H}-5), 7.30(\mathrm{tm}, J=7.5 \mathrm{~Hz}$, $\left.1 \mathrm{H}, \mathrm{H}-4^{\prime}\right), 7.40-7.44\left(\mathrm{~m}, 2 \mathrm{H}, \mathrm{H}-3^{\prime}\right), 7.47(\mathrm{dm}, J=7.5 \mathrm{~Hz}, 1 \mathrm{H}, \mathrm{H}-4), 7.64-7.68\left(\mathrm{~m}, 2 \mathrm{H}, \mathrm{H}-2^{\prime}\right)$, 8.15 (br s, $1 \mathrm{H}, \mathrm{NH}) .{ }^{13} \mathrm{C}$ NMR $\left(125 \mathrm{MHz}, \mathrm{CDCl}_{3}\right): \delta 16.7\left(\mathrm{CH}_{3} \mathrm{Ar}\right), 100.6$ (C-3), $118.4(\mathrm{C}-4)$, 120.0 (C-7), 120.4 (C-5), 122.9 (C-6), 125.2 (C-2'), 127.6 (C-4'), 128.8 (C-3a), 129.0 (C-3'), 132.5 $\left(\mathrm{C}-1^{\prime}\right), 136.4(\mathrm{C}-7 \mathrm{a}), 137.6$ (C-2).

\subsubsection{7-Methoxy-2-phenyl-1H-indole (6c)}

Following general method B, a mixture of $2 \mathrm{a}(0.086 \mathrm{~g}, 0.84 \mathrm{mmol}), 1 \mathrm{c}(0.110 \mathrm{~g}$, $0.89 \mathrm{mmol})$, and $\mathrm{Hg}_{2} \mathrm{Cl}_{2}(0.020 \mathrm{~g}, 0.04 \mathrm{mmol})$ was stirred at $60{ }^{\circ} \mathrm{C}$ for $4 \mathrm{~h}$. It was then reacted with DMSO $(4.2 \mathrm{~mL}), \mathrm{Cu}(\mathrm{OAc})_{2}(0.230 \mathrm{~g}, 1.27 \mathrm{mmol})$, and $\mathrm{Pd}(\mathrm{OAc})_{2}(0.038 \mathrm{~g}$, $0.17 \mathrm{mmol}$ ) to furnish $6 \mathrm{c}(0.149 \mathrm{~g}, 79 \%)$ as an amber solid. $R f 0.67$ (hexane/EtOAc, 7:3); mp 63-64 ${ }^{\circ} \mathrm{C}$ (Lit. 94-95 ${ }^{\circ} \mathrm{C}$ [66]). IR (ATR): $\bar{v} 3429,1608,1581,1505,1485,1453,1401,1332$, 1316, 1258, 1225, 1097, 798, 772, 753, $730 \mathrm{~cm}^{-1} .{ }^{1} \mathrm{H}$ NMR $\left(600 \mathrm{MHz}, \mathrm{CDCl}_{3}\right): \delta 4.00(\mathrm{~s}, 3 \mathrm{H}$, $\left.\mathrm{CH}_{3} \mathrm{O}\right), 6.66(\mathrm{~d}, J=7.8 \mathrm{~Hz}, 1 \mathrm{H}, \mathrm{H}-6), 6.81(\mathrm{~d}, J=2.4,1 \mathrm{H}, \mathrm{H}-3), 7.04(\mathrm{t}, J=7.8 \mathrm{~Hz}, 1 \mathrm{H}, \mathrm{H}-5)$, $7.24(\mathrm{~d}, J=7.8 \mathrm{~Hz}, 1 \mathrm{H}, \mathrm{H}-4), 7.31-7.34\left(\mathrm{~m}, 1 \mathrm{H}, \mathrm{H}-4^{\prime}\right), 7.42-7.46\left(\mathrm{~m}, 2 \mathrm{H}, \mathrm{H}-3^{\prime}\right), 7.68-7.70(\mathrm{~m}$, $\left.2 \mathrm{H}, \mathrm{H}-2^{\prime}\right), 8.56$ (br s, $\left.1 \mathrm{H}, \mathrm{NH}\right) .{ }^{13} \mathrm{C} \mathrm{NMR}\left(150 \mathrm{MHz}, \mathrm{CDCl}_{3}\right): \delta 55.3\left(\mathrm{CH}_{3} \mathrm{O}\right), 100.2(\mathrm{C}-3)$, 102.1 (C-6), 113.3 (C-4), 120.5 (C-5), 125.1 (C-2'), 127.3 (C-7a), 127.6 (C-4'), 129.0 (C-3'), 130.4 (C-3a), 132.4 (C-1'), 137.5 (C-2), 145.9 (C-7). HRMS (EI): $m / z$ [M $\left.\mathrm{M}^{+}\right]$calcd for $\mathrm{C}_{15} \mathrm{H}_{13} \mathrm{NO}$ : 223.0997; found: 223.0994 .

\subsubsection{6-Methyl-2-phenyl-1H-indole (6d). 4-Methyl-2-phenyl-1H-indole (6d')}

Following general method B, a mixture of $2 \mathrm{a}(0.076 \mathrm{~g}, 0.75 \mathrm{mmol}), 1 \mathrm{~d}(0.084 \mathrm{~g}$, $0.79 \mathrm{mmol})$, and $\mathrm{Hg}_{2} \mathrm{Cl}_{2}(0.019 \mathrm{~g}, 0.04 \mathrm{mmol})$ was stirred at $60{ }^{\circ} \mathrm{C}$ for $4 \mathrm{~h}$. It was then reacted with DMSO $(3.7 \mathrm{~mL}), \mathrm{Cu}(\mathrm{OAc})_{2}(0.204 \mathrm{~g}, 1.12 \mathrm{mmol})$, and $\mathrm{Pd}(\mathrm{OAc})_{2}(0.034 \mathrm{~g}$, $0.15 \mathbf{m m o l}$ ) to afford a mixture of $\mathbf{6} \mathbf{d} / \mathbf{6} \mathbf{d}^{\prime}(88: 12)$, which was separated to provide $\mathbf{6 d}$ $(0.097 \mathrm{~g}, 63 \%)$ as a pale yellow solid. $R f 0.70$ (hexane/EtOAc, 7:3); mp 186-187 ${ }^{\circ} \mathrm{C}$ (Lit. $189-190{ }^{\circ} \mathrm{C}$ [102], 190-192 ${ }^{\circ} \mathrm{C}$ [103]). IR (ATR): $\bar{v} 3429,1454,1384,1350,1232,814,760,741$, 
$687 \mathrm{~cm}^{-1} .{ }^{1} \mathrm{H}$ NMR (600 MHz, $\left.\mathrm{CDCl}_{3}\right): \delta 2.47$ (s, 3H, $\left.\mathrm{CH}_{3} \mathrm{Ar}\right), 6.78$ (dd, J = 2.4, $0.9 \mathrm{~Hz}, 1 \mathrm{H}$, H-3), $6.96(\mathrm{dd}, J=8.4,0.9 \mathrm{~Hz}, 1 \mathrm{H}, \mathrm{H}-5), 7.20$ (d, J = 0.9 Hz, 1H, H-7), 7.29-7.32 (m, 1H, H-4' $)$, $7.41-7.45\left(\mathrm{~m}, 2 \mathrm{H}, \mathrm{H}-3^{\prime}\right), 7.51$ (d, J = 8.4, 1H, H-4), 7.63-7.66 (m, 2H, H-2'), 8.21 (br s, 1H, NH). ${ }^{13} \mathrm{C} \mathrm{NMR}\left(150 \mathrm{MHz}, \mathrm{CDCl}_{3}\right): \delta 21.8\left(\mathrm{CH}_{3} \mathrm{Ar}\right), 99.8$ (C-3), 110.8 (C-7), 120.3 (C-4), $122.0(\mathrm{C}-5)$, 125.0 (C-2'), 127.1 (C-3a), 127.5 (C-4'), 129.0 (C-3'), 132.3 (C-6), 132.6 (C-1'), 137.2 (C-7a), 137.3 (C-2). Data for 6d: MS (70 eV): m/z $207\left(\mathrm{M}^{+}, 100\right), 206(60), 178(5), 130$ (7), 77 (18), 44 (15). Data for 6d': MS (70 eV): m/z $207\left(\mathrm{M}^{+}, 10\right), 177$ (13), 169 (11), 143 (7), 119 (14), 77 (30), $44(100)$.

\subsubsection{6-Methoxy-2-phenyl-1H-indole (6e). 4-Methoxy-2-phenyl-1H-indole (6 $\left.\mathbf{e}^{\prime}\right)$}

Following general method B, a mixture of $\mathbf{2 a}(0.085 \mathrm{~g}, 0.83 \mathrm{mmol})$, 1e $(0.107 \mathrm{~g}$, $0.87 \mathrm{mmol})$, and $\mathrm{Hg}_{2} \mathrm{Cl}_{2}(0.019 \mathrm{~g}, 0.04 \mathrm{mmol})$ was stirred at $60{ }^{\circ} \mathrm{C}$ for $4 \mathrm{~h}$. It was then reacted with DMSO $(4.4 \mathrm{~mL}), \mathrm{Cu}(\mathrm{OAc})_{2}(0.225 \mathrm{~g}, 1.24 \mathrm{mmol})$, and $\mathrm{Pd}(\mathrm{OAc})_{2}(0.038 \mathrm{~g}$, $0.17 \mathrm{mmol})$, leading to a mixture of $\mathbf{6 e} / \mathbf{6} \mathbf{e}^{\mathbf{\prime}}(93: 7)$ [66], which was separated by column chromatography over silica gel (30 g/g crude, hexane/EtOAc, 98:2) to give 6e (0.138 g, $75 \%$ ) as a brown solid. $R f 0.60$ (hexane/EtOAc, 7:3); mp 160-161 ${ }^{\circ} \mathrm{C}$ (Lit. 177-178 ${ }^{\circ} \mathrm{C}$ [66]; 173-176 ${ }^{\circ} \mathrm{C}$ [102]). IR (ATR): $\bar{v} 3396,1625,1446,1257,1200,1158,1016,823,756 \mathrm{~cm}^{-1} .{ }^{1} \mathrm{H}$ $\operatorname{NMR}\left(600 \mathrm{MHz}, \mathrm{CDCl}_{3}\right): \delta 3.86\left(\mathrm{~s}, 3 \mathrm{H}, \mathrm{CH}_{3} \mathrm{O}\right), 6.76(\mathrm{~d}, J=1.8,1 \mathrm{H}, \mathrm{H}-3), 6.80(\mathrm{dd}, J=8.4$, $2.4 \mathrm{~Hz}, 1 \mathrm{H}, \mathrm{H}-5), 6.90$ (d, J = 2.4, 1H, H-7), 7.27-7.31 (m, 1H, H-4'), 7.41-7.44 (m, 2H, H-3'), $7.50(\mathrm{~d}, J=8.4,1 \mathrm{H}, \mathrm{H}-4), 7.60-7.63\left(\mathrm{~m}, 2 \mathrm{H}, \mathrm{H}-2^{\prime}\right), 8.24$ (br s, $\left.1 \mathrm{H}, \mathrm{NH}\right) .{ }^{13} \mathrm{C} \mathrm{NMR}(150 \mathrm{MHz}$, $\left.\mathrm{CDCl}_{3}\right): \delta 55.6\left(\mathrm{CH}_{3} \mathrm{O}\right), 94.4(\mathrm{C}-7), 99.8,(\mathrm{C}-3), 110.2(\mathrm{C}-5), 121.3(\mathrm{C}-4), 123.5(\mathrm{C}-3 \mathrm{a}), 124.7$

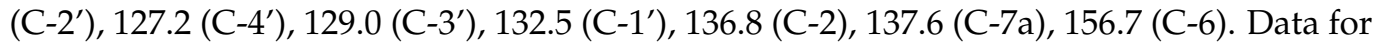
6e: MS (70 eV): m/z $223\left(\mathrm{M}^{+}, 77\right), 208$ (100), 180 (23), 152 (17), 77 (3). Data for 6e': MS (70 eV):

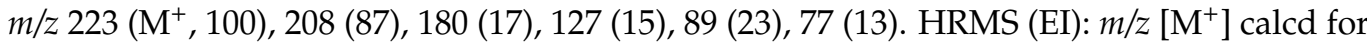
$\mathrm{C}_{15} \mathrm{H}_{13} \mathrm{NO}$ : 223.0997; found: 223.0991.

\subsubsection{6-Chloro-2-phenyl-1H-indole (6f). 4-Chloro-2-phenyl-1H-indole (6f')}

Following general method $\mathrm{B}$, a mixture of $\mathbf{2 a}(0.079 \mathrm{~g}, 0.77 \mathrm{mmol}), \mathbf{1 f}(0.103 \mathrm{~g}, 0.81 \mathrm{mmol})$, and $\mathrm{Hg}_{2} \mathrm{Cl}_{2}(0.019 \mathrm{~g}, 0.04 \mathrm{mmol})$ was stirred at $60^{\circ} \mathrm{C}$ for $4 \mathrm{~h}$. It was then reacted with DMSO $(4.3 \mathrm{~mL}), \mathrm{Cu}(\mathrm{OAc})_{2}(0.211 \mathrm{~g}, 1.16 \mathrm{mmol})$, and $\mathrm{Pd}(\mathrm{OAc})_{2}(0.034 \mathrm{~g}, 0.15 \mathrm{mmol})$, resulting in a mixture of $\mathbf{6 f} / \mathbf{6} \mathbf{f}^{\prime}$ (81:19), which was separated by column chromatography over silica gel (30 g/g crude, hexane/EtOAc, 98:2) to obtain $6 \mathrm{f}(0.109 \mathrm{~g}, 62 \%)$ as a yellow solid. $R f 0.70$ (hexane/EtOAc, 7:3); mp 181-182 ${ }^{\circ} \mathrm{C}$ (Lit. 171-173 ${ }^{\circ} \mathrm{C}$ [104]; 182-183 ${ }^{\circ} \mathrm{C}$ [105]). IR (ATR): $\bar{v}$ $3429,1453,1310,1067,876,805,758,736,688 \mathrm{~cm}^{-1} .{ }^{1} \mathrm{H} \mathrm{NMR}\left(500 \mathrm{MHz}, \mathrm{CDCl}_{3}\right): \delta 6.79(\mathrm{~d}$, $J=2.0 \mathrm{~Hz}, 1 \mathrm{H}, \mathrm{H}-3), 7.09$ (dd, $J=8.5,1.5 \mathrm{~Hz}, 1 \mathrm{H}, \mathrm{H}-5), 7.34$ (br t, $\left.J=7.5 \mathrm{~Hz}, 1 \mathrm{H}, \mathrm{H}-4^{\prime}\right), 7.39$ $(\mathrm{d}, J=1.5 \mathrm{~Hz}, 1 \mathrm{H}, \mathrm{H}-7), 7.45\left(\mathrm{t}, J=7.5 \mathrm{~Hz}, 2 \mathrm{H}, \mathrm{H}-3^{\prime}\right), 7.52(\mathrm{~d}, J=8.5 \mathrm{~Hz}, 1 \mathrm{H}, \mathrm{H}-4), 7.65(\mathrm{~d}$, $\left.J=7.5 \mathrm{~Hz}, 2 \mathrm{H}, \mathrm{H}-2^{\prime}\right), 8.32$ (br s, $\left.1 \mathrm{H}, \mathrm{NH}\right) .{ }^{13} \mathrm{C} \mathrm{NMR}\left(125 \mathrm{MHz}, \mathrm{CDCl}_{3}\right): \delta 100.0(\mathrm{C}-3), 110.8$ (C-7), 121.0 (C-5), 121.5 (C-4), 125.2 (C-2') , 127.8 (C-3a), 128.0 (C-4'), 128.1 (C-6), 129.1 (C-3'), $131.9\left(\mathrm{C}-1^{\prime}\right), 137.1$ (C-7a), 138.6 (C-2). Data for 6f: MS (70 eV): $m / z 229\left(\mathrm{M}^{+}+2,37\right), 227\left(\mathrm{M}^{+}\right.$, 100), 190 (8), 165 (23), 114 (5), 89 (13), 77 (3). Data for $6 f^{\prime}:$ MS (70 eV): m/z $229\left(\mathrm{M}^{+}+2,30\right)$, $227\left(\mathrm{M}^{+}, 100\right), 190(8), 165(17), 89(15)$.

\subsubsection{5-Methyl-2-phenyl-1H-indole (6g)}

Following general method B, a mixture of $\mathbf{2 a}(0.083 \mathrm{~g}, 0.81 \mathrm{mmol}), \mathbf{1 g}(0.092 \mathrm{~g}$, $0.86 \mathrm{mmol})$, and $\mathrm{Hg}_{2} \mathrm{Cl}_{2}(0.019 \mathrm{~g}, 0.04 \mathrm{mmol})$ was stirred at $60{ }^{\circ} \mathrm{C}$ for $2 \mathrm{~h}$. It was then reacted with DMSO $(4.1 \mathrm{~mL}), \mathrm{Cu}(\mathrm{OAc})_{2}(0.222 \mathrm{~g}, 1.22 \mathrm{mmol})$, and $\mathrm{Pd}(\mathrm{OAc})_{2}(0.036 \mathrm{~g}$, $0.16 \mathrm{mmol})$ to produce $6 \mathrm{~g}(0.103 \mathrm{~g}, 61 \%)$ as a pale-yellow solid. $R f 0.70$ (hexane/EtOAc, 7:3); mp 214-215 ${ }^{\circ} \mathrm{C}$ (Lit. $216-218^{\circ} \mathrm{C}$ [66]; 211-213 ${ }^{\circ} \mathrm{C}$ [102]; $218-220{ }^{\circ} \mathrm{C}$ [103]). IR (ATR): $\bar{v}$ $3405,1603,1449,1406,1299,1202,1079,804,799,737,761,686 \mathrm{~cm}^{-1} .{ }^{1} \mathrm{H}$ NMR $(600 \mathrm{MHz}$, $\left.\mathrm{CDCl}_{3}\right): \delta 2.45\left(\mathrm{~s}, 3 \mathrm{H}, \mathrm{CH}_{3}\right), 6.75(\mathrm{dd}, J=2.4,0.6 \mathrm{~Hz}, 1 \mathrm{H}, \mathrm{H}-3), 7.02(\mathrm{dd}, J=8.4,1.2 \mathrm{~Hz}$, $1 \mathrm{H}, \mathrm{H}-6), 7.28$ (d, J = 8.4 Hz, 1H, H-7), 7.29-7.32 (m, 1H, H-4'), 7.41 (dd, J = 1.2, $0.6 \mathrm{~Hz}$, 1H, H-4), 7.41-7.44 (m, 2H, H-3'), 7.63-7.66 (m, 2H, H-2'), 8.23 (br s, 1H, NH). ${ }^{13} \mathrm{C}$ NMR $\left(150 \mathrm{MHz}, \mathrm{CDCl}_{3}\right): \delta 21.5\left(\mathrm{CH}_{3}\right), 99.5(\mathrm{C}-3), 110.5(\mathrm{C}-7), 120.3(\mathrm{C}-4), 124.0(\mathrm{C}-6), 125.0\left(\mathrm{C}-2^{\prime}\right)$, 127.6 (C-4'), 129.0 (C-3'), 129.46 (C-5), 129.54 (C-3a), 132.5 (C-1'), 135.2 (C-7a), 137.9 (C-2). 


\subsubsection{5-Methoxy-2-phenyl-1H-indole (6h)}

Following general method B, a mixture of $\mathbf{2 a}(0.083 \mathrm{~g}, 0.82 \mathrm{mmol}), \mathbf{1 i}(0.106 \mathrm{~g}, 0.86 \mathrm{mmol})$, and $\mathrm{Hg}_{2} \mathrm{Cl}_{2}(0.019 \mathrm{~g}, 0.04 \mathrm{mmol})$ was stirred at $60^{\circ} \mathrm{C}$ for $2 \mathrm{~h}$. It was then reacted with DMSO (4.1 mL), $\mathrm{Cu}(\mathrm{OAc})_{2}(0.222 \mathrm{~g}, 1.22 \mathrm{mmol})$, and $\mathrm{Pd}(\mathrm{OAc})_{2}(0.036 \mathrm{~g}, 0.16 \mathrm{mmol})$ to generate $6 \mathrm{~h}(0.146 \mathrm{~g}, 80 \%)$ as a yellow solid. $\mathrm{Rf} 0.60$ (hexane/EtOAc, 7:3).

Following general method $\mathrm{C}$, a mixture of $5 \mathbf{i}(0.060 \mathrm{~g}, 0.27 \mathrm{mmol})$, DMSO $(1.33 \mathrm{~mL})$, $\mathrm{Cu}(\mathrm{OAc})_{2}(0.073 \mathrm{~g}, 0.40 \mathrm{mmol})$, and $\mathrm{Pd}(\mathrm{OAc})_{2}(0.012 \mathrm{~g}, 0.054 \mathrm{mmol})$ was reacted to afford $6 \mathbf{h}(0.037 \mathrm{~g}, 62 \%)$ as a pale brownish solid. $R f 0.60$ (hexane/EtOAc, 7:3). mp 168-169 ${ }^{\circ} \mathrm{C}$ (Lit. $169-170{ }^{\circ} \mathrm{C}$ [66], $166-169{ }^{\circ} \mathrm{C}$ [101], $160-162{ }^{\circ} \mathrm{C}$ [102]). IR (KBr): v 3415, 1615, 1479, $1208,1148,1030,765 \mathrm{~cm}^{-1} .{ }^{1} \mathrm{H}$ NMR $\left(600 \mathrm{MHz}, \mathrm{CDCl}_{3}\right): \delta 3.87\left(\mathrm{~s}, 3 \mathrm{H}, \mathrm{CH}_{3} \mathrm{O}\right), 6.76(\mathrm{dd}$, $J=2.4,1.2 \mathrm{~Hz}, 1 \mathrm{H}, \mathrm{H}-3), 6.86(\mathrm{dd}, J=9.0,2.4 \mathrm{~Hz}, 1 \mathrm{H}, \mathrm{H}-6), 7.09$ (d, $J=2.4 \mathrm{~Hz}, 1 \mathrm{H}, \mathrm{H}-4)$, 7.29 (d, $J=9.0 \mathrm{~Hz}, 1 \mathrm{H}, \mathrm{H}-7), 7.30-7.33\left(\mathrm{~m}, 1 \mathrm{H}, \mathrm{H}-4^{\prime}\right), 7.41-7.46\left(\mathrm{~m}, 2 \mathrm{H}, \mathrm{H}-3^{\prime}\right), 7.63-7.66$ $\left(\mathrm{m}, 2 \mathrm{H}, \mathrm{H}-2^{\prime}\right), 8.21(\mathrm{br} \mathrm{s}, 1 \mathrm{H}, \mathrm{NH}) .{ }^{13} \mathrm{C} \mathrm{NMR}\left(150 \mathrm{MHz}, \mathrm{CDCl}_{3}\right): \delta 55.8\left(\mathrm{CH}_{3} \mathrm{O}\right), 99.9(\mathrm{C}-3)$, 102.3 (C-4), 111.6 (C-7), 112.6 (C-6), 125.1 (C-2'), 127.6 (C-4'), 129.0 (C-3'), 129.7 (C-3a), 132.0 (C-7a), 132.5 (C-1'), 138.6 (C-2), 154.5 (C-5).

\subsubsection{5-Chloro-2-phenyl-1H-indole (6i)}

Following general method B, a mixture of $\mathbf{2 a}(0.085 \mathrm{~g}, 0.83 \mathrm{mmol}), \mathbf{1 j}(0.111 \mathrm{~g}, 0.87 \mathrm{mmol})$, and $\mathrm{Hg}_{2} \mathrm{Cl}_{2}(0.019 \mathrm{~g}, 0.04 \mathrm{mmol})$ was stirred at $60{ }^{\circ} \mathrm{C}$ for $2 \mathrm{~h}$. It was then reacted with DMSO (4.1 mL), $\mathrm{Cu}(\mathrm{OAc})_{2}(0.225 \mathrm{~g}, 1.24 \mathrm{mmol})$, and $\mathrm{Pd}(\mathrm{OAc})_{2}(0.037 \mathrm{~g}, 0.17 \mathrm{mmol})$ to give $6 \mathbf{i}(0.134 \mathrm{~g}, 71 \%)$ as a yellow solid. $R f 0.60$ (hexane/EtOAc, 7:3).

Following general method $\mathrm{C}$, a mixture of $5 \mathbf{j}(0.081 \mathrm{~g}, 0.35 \mathrm{mmol})$, DMSO $(1.77 \mathrm{~mL})$, $\mathrm{Cu}(\mathrm{OAc})_{2}(0.073 \mathrm{~g}, 0.53 \mathrm{mmol})$, and $\mathrm{Pd}(\mathrm{OAc})_{2}(0.016 \mathrm{~g}, 0.07 \mathrm{mmol})$ was reacted to provide $6 \mathbf{i}(0.046 \mathrm{~g}, 57 \%)$ as a yellow solid. Rf 0.60 (hexane/EtOAc, 7:3); mp 195-196 ${ }^{\circ} \mathrm{C}$ (Lit. 196-197 ${ }^{\circ} \mathrm{C}$ [66], 198-200 ${ }^{\circ} \mathrm{C}$ [103]). IR (ATR): $\bar{v} 3429,1452,1313,1065,876,803,754,736$, $687 \mathrm{~cm}^{-1} .{ }^{1} \mathrm{H}$ NMR $\left(600 \mathrm{MHz}, \mathrm{CDCl}_{3}\right): \delta 6.76(\mathrm{~d}, J=1.8 \mathrm{~Hz}, 1 \mathrm{H}, \mathrm{H}-3), 7.14(\mathrm{dd}, J=8.4$, $1.8 \mathrm{~Hz}, 1 \mathrm{H}, \mathrm{H}-6), 7.31(\mathrm{~d}, J=8.4 \mathrm{~Hz}, 1 \mathrm{H}, \mathrm{H}-7), 7.35\left(\mathrm{t}, J=7.5 \mathrm{~Hz}, 1 \mathrm{H}, \mathrm{H}-4^{\prime}\right), 7.45(\mathrm{t}, J=7.5 \mathrm{~Hz}$, $\left.2 \mathrm{H}, \mathrm{H}-3^{\prime}\right), 7.59$ (d, J = $\left.1.8 \mathrm{~Hz}, 1 \mathrm{H}, \mathrm{H}-4\right), 7.65\left(\mathrm{~d}, J=7.5 \mathrm{~Hz}, 2 \mathrm{H}, \mathrm{H}-2^{\prime}\right), 8.35$ (br s, $\left.1 \mathrm{H}, \mathrm{NH}\right)$. ${ }^{13} \mathrm{C}$ NMR (150 MHz, CDCl 3 ): $\delta 99.6$ (C-3), 111.8 (C-7), 120.0 (C-4), 122.6 (C-6), 125.2 (C-2'), 125.9 (C-5), 128.1 (C-4'), 129.1 (C-3'), 130.3 (C-3a), 131.9 (C-1'), 135.1 (C-7a), 139.3 (C-2).

\subsubsection{7-Bromo-5-methyl-2-phenyl-1H-indole (6j)}

Following general method B, a mixture of $2 \mathrm{a}(0.085 \mathrm{~g}, 0.83 \mathrm{mmol}), 1 \mathrm{k}(0.163 \mathrm{~g}$, $0.88 \mathrm{mmol})$, and $\mathrm{Hg}_{2} \mathrm{Cl}_{2}(0.020 \mathrm{~g}, 0.04 \mathrm{mmol})$ was stirred at $60{ }^{\circ} \mathrm{C}$ for $8 \mathrm{~h}$. It was then reacted with DMSO $(4.2 \mathrm{~mL}), \mathrm{Cu}(\mathrm{OAc})_{2}(0.227 \mathrm{~g}, 1.25 \mathrm{mmol})$, and $\mathrm{Pd}(\mathrm{OAc})_{2}(0.037 \mathrm{~g}$, $0.17 \mathrm{mmol}$ ) to obtain $\mathbf{6 j}(0.085 \mathrm{~g}, 36 \%)$ as a brown solid. $R f 0.73$ (hexane/EtOAc, 7:3); $\mathrm{mp}$ $75-77^{\circ} \mathrm{C}$ (Lit. $130-131^{\circ} \mathrm{C}$ [106]). IR (film): v 3446, 3036, 2918, 1605, 1568, 1477, 1449, 1395, 1310, 1214, 856, 840, 759, 734, $690 \mathrm{~cm}^{-1} .{ }^{1} \mathrm{H}$ NMR $\left(500 \mathrm{MHz}, \mathrm{CDCl}_{3}\right): \delta 2.42\left(\mathrm{~s}, 3 \mathrm{H}, \mathrm{CH}_{3}\right)$, 6.78 (dd, $J=2.5,0.6 \mathrm{~Hz}, 1 \mathrm{H}, \mathrm{H}-3), 7.18$ (br s, 1H, H-6), 7.32-7.36 (m, 1H, H-4, H-4'), 7.42-7.47 $\left(\mathrm{m}, 2 \mathrm{H}, \mathrm{H}-3^{\prime}\right), 7.65-7.68\left(\mathrm{~m}, 2 \mathrm{H}, \mathrm{H}-2^{\prime}\right), 8.32(\mathrm{br} \mathrm{s}, 1 \mathrm{H}, \mathrm{NH}) .{ }^{13} \mathrm{C} \mathrm{NMR}\left(125 \mathrm{MHz}, \mathrm{CDCl}_{3}\right): \delta$ $21.2\left(\mathrm{CH}_{3}\right), 100.5$ (C-3), 103.9 (C-7), 119.5 (C-4), $125.3\left(\mathrm{C}-2^{\prime}\right), 125.9$ (C-6), $128.0\left(\mathrm{C}-4^{\prime}\right), 129.0$ (C-3'), 130.4 (C-3a), 131.1 (C-5), 131.9 (C-1'), 133.8 (C-7a), 138.6 (C-2). HRMS (EI): m/z [M $\left.{ }^{+}\right]$ calcd for $\mathrm{C}_{15} \mathrm{H}_{12} \mathrm{NBr}$ : 285.0153; found: 285.0160 .

\subsubsection{5-Methoxy-2-(p-tolyl)-1H-indole (6k)}

Following general method B, a mixture of $\mathbf{2 b}(0.094 \mathrm{~g}, 0.81 \mathrm{mmol}), \mathbf{1 i}(0.105 \mathrm{~g}$, $0.85 \mathrm{mmol})$, and $\mathrm{Hg}_{2} \mathrm{Cl}_{2}(0.019 \mathrm{~g}, 0.04 \mathrm{mmol})$ was stirred at $60{ }^{\circ} \mathrm{C}$ for $2 \mathrm{~h}$. It was then reacted with $\mathrm{DMSO}(4.1 \mathrm{~mL}), \mathrm{Cu}(\mathrm{OAc})_{2}(0.222 \mathrm{~g}, 1.22 \mathrm{mmol})$, and $\mathrm{Pd}(\mathrm{OAc})_{2}(0.036 \mathrm{~g}$, $0.16 \mathrm{mmol}$ ) to give $6 \mathbf{k}(0.122 \mathrm{~g}, 64 \%)$ as a yellow solid. $R f 0.70$ (hexane/EtOAc, 7:3); mp 184-186 ${ }^{\circ} \mathrm{C}$ (Lit. 186-187 ${ }^{\circ} \mathrm{C}$ [66]). IR (ATR): v 3424, 1621, 1543, 1479, 1452, 1301, 1217, $1153,1115,1029,823,789 \mathrm{~cm}^{-1} .{ }^{1} \mathrm{H}$ NMR $\left(500 \mathrm{MHz}, \mathrm{CDCl}_{3}\right): \delta 2.39\left(\mathrm{~s}, 3 \mathrm{H}, \mathrm{CH}_{3} \mathrm{Ar}\right), 3.86$ $\left(\mathrm{s}, 3 \mathrm{H}, \mathrm{CH}_{3} \mathrm{O}\right), 6.71(\mathrm{dd}, J=2.5,1.0 \mathrm{~Hz}, 1 \mathrm{H}, \mathrm{H}-3), 6.84(\mathrm{dd}, J=8.5,2.5 \mathrm{~Hz}, 1 \mathrm{H}, \mathrm{H}-6), 7.08$ $(\mathrm{d}, J=2.5 \mathrm{~Hz}, 1 \mathrm{H}, \mathrm{H}-4), 7.21-7.25\left(\mathrm{~m}, 2 \mathrm{H}, \mathrm{H}-3^{\prime}\right), 7.26$ (d, J = 8.5 Hz, 1H, H-7), 7.51-7.55 (m, 2H, H-2'), 8.17 (br s, $1 \mathrm{H}, \mathrm{NH}) .{ }^{13} \mathrm{C} \mathrm{NMR}\left(125 \mathrm{MHz}, \mathrm{CDCl}_{3}\right): \delta 21.2\left(\mathrm{CH}_{3} \mathrm{Ar}\right), 55.8\left(\mathrm{CH}_{3} \mathrm{O}\right)$, 
99.3 (C-3), 102.2 (C-4), 111.5 (C-7), 112.3 (C-6), 125.0 (C-2'), 129.6 (C-1' or C-3a), 129.7 (C-3'), 129.8 (C-3a or C-1'), 131.9 (C-7a), 137.6 (C-4'), 138.8 (C-2), 154.5 (C-5).

3.6.12. 2-(4-Cyanophenyl)-5-methoxy- $1 H$-indole (61)

Following general method B, a mixture of $2 \mathrm{c}(0.078 \mathrm{~g}, 0.61 \mathrm{mmol}), \mathbf{i}(0.079 \mathrm{~g}, 0.64 \mathrm{mmol})$, and $\mathrm{Hg}_{2} \mathrm{Cl}_{2}(0.014 \mathrm{~g}, 0.03 \mathrm{mmol})$ was stirred at $60^{\circ} \mathrm{C}$ for $2 \mathrm{~h}$. It was then reacted with DMSO (3.1 mL), Cu(OAc) $2(0.167 \mathrm{~g}, 0.92 \mathrm{mmol})$, and $\mathrm{Pd}(\mathrm{OAc})_{2}(0.027 \mathrm{~g}, 0.12 \mathrm{mmol})$ to produce $61(0.050 \mathrm{~g}, 33 \%)$ as yellow crystals. $R f 0.47$ (hexane/EtOAc, 7:3); $\mathrm{mp} 191-192{ }^{\circ} \mathrm{C}$ (Lit. $195-196{ }^{\circ} \mathrm{C}$ [66]). IR (KBr): $\bar{v} 3377,2219,1606,1445,1209,1030,836,789 \mathrm{~cm}^{-1} .{ }^{1} \mathrm{H}$ $\operatorname{NMR}\left(500 \mathrm{MHz}, \mathrm{CDCl}_{3}\right): \delta 3.87\left(\mathrm{~s}, 3 \mathrm{H}, \mathrm{CH}_{3} \mathrm{O}\right), 6.88(\mathrm{dd}, J=1.5,0.5 \mathrm{~Hz}, 1 \mathrm{H}, \mathrm{H}-3), 6.92$ $(\mathrm{dd}, J=8.7,2.5 \mathrm{~Hz}, 1 \mathrm{H}, \mathrm{H}-6), 7.09(\mathrm{~d}, J=2.5 \mathrm{~Hz}, 1 \mathrm{H}, \mathrm{H}-4), 7.31(\mathrm{dd}, J=8.7,0.5 \mathrm{~Hz}, 1 \mathrm{H}$, $\mathrm{H}-7), 7.69-7.73$ (m, 4H, H-2', H-3'), 8.30 (br s, $1 \mathrm{H}, \mathrm{NH}) .{ }^{13} \mathrm{C}$ NMR $\left(125 \mathrm{MHz}, \mathrm{CDCl}_{3}\right): \delta 55.8$ $\left(\mathrm{CH}_{3} \mathrm{O}\right) 102.3(\mathrm{C}-4), 102.4(\mathrm{C}-3), 110.5\left(\mathrm{C}-4^{\prime}\right), 112.0(\mathrm{C}-7), 114.3(\mathrm{C}-6), 118.8(\mathrm{CN}), 125.1\left(\mathrm{C}-2^{\prime}\right)$, 129.4 (C-3a), 132.6 (C-7a), 132.8 (C-3'), 136.1 (C-2), 136.6 (C-1'), 154.8 (C-5). HRMS (EI): m/z $\left[\mathrm{M}^{+}\right]$calcd for $\mathrm{C}_{16} \mathrm{H}_{12} \mathrm{~N}_{2} \mathrm{O}: 248.0950$; found: 248.0943 .

\subsubsection{5-Methoxy-2-(4-methoxyphenyl)-1H-indole (6m)}

Following general method B, a mixture of $2 \mathbf{d}(0.075 \mathrm{~g}, 0.57 \mathrm{mmol}), \mathbf{1 i}(0.074 \mathrm{~g}$, $0.60 \mathrm{mmol})$, and $\mathrm{Hg}_{2} \mathrm{Cl}_{2}(0.014 \mathrm{~g}, 0.03 \mathrm{mmol})$ was stirred at $60{ }^{\circ} \mathrm{C}$ for $2 \mathrm{~h}$. It was then reacted with DMSO $(3.1 \mathrm{~mL}), \mathrm{Cu}(\mathrm{OAc})_{2}(0.156 \mathrm{~g}, 0.86 \mathrm{mmol})$, and $\mathrm{Pd}(\mathrm{OAc})_{2}(0.025 \mathrm{~g}$, $0.11 \mathrm{mmol}$ ) to generate $6 \mathrm{~m}(0.122 \mathrm{~g}, 84 \%)$ as a colorless crystalline solid. $R f 0.53$ (hexane/EtOAc, 7:3); mp 218-219 ${ }^{\circ} \mathrm{C}$ (Lit. 218-219 ${ }^{\circ} \mathrm{C}$ [66]). IR (ATR): $\bar{v} 3430,1543,1480,1456$, 1254, 1217, 1155, 1018, 829, $777 \mathrm{~cm}^{-1} .{ }^{1} \mathrm{H}$ NMR $\left(600 \mathrm{MHz}, \mathrm{CDCl}_{3}\right): \delta 3.85\left(\mathrm{~s}, 3 \mathrm{H}, \mathrm{CH}_{3} \mathrm{O}-\mathrm{C}^{\prime}\right)$, $3.86\left(\mathrm{~s}, 3 \mathrm{H}, \mathrm{CH}_{3} \mathrm{O}-\mathrm{C} 5\right), 6.64(\mathrm{~d}, J=1.2 \mathrm{~Hz}, 1 \mathrm{H}, \mathrm{H}-3), 6.83(\mathrm{dd}, J=8.4,2.4 \mathrm{~Hz}, 1 \mathrm{H}, \mathrm{H}-6)$, 6.96-6.99 (m, 2H, H-3'), $7.10(\mathrm{~d}, J=2.4 \mathrm{~Hz}, 1 \mathrm{H}, \mathrm{H}-4), 7.27(\mathrm{~d}, J=8.4 \mathrm{~Hz}, 1 \mathrm{H}, \mathrm{H}-7), 7.56-7.59$ $\left(\mathrm{m}, 2 \mathrm{H}, \mathrm{H}-2^{\prime}\right), 8.13(\mathrm{br} \mathrm{s}, 1 \mathrm{H}, \mathrm{NH}) .{ }^{13} \mathrm{C}$ NMR $\left(150 \mathrm{MHz}, \mathrm{CDCl}_{3}\right): \delta 55.4\left(\mathrm{CH}_{3} \mathrm{O}\right), 55.9\left(\mathrm{CH}_{3} \mathrm{O}\right)$, 98.7 (C-3), 102.2 (C-4), 111.4 (C-7), 112.0 (C-6), 114.5 (C-3'), 125.3 (C-1'), 126.4 (C-2'), 129.9 (C-3a), 131.8 (C-7a), 138.7 (C-2), 154.5 (C-5), 159.3 (C-4').

\subsubsection{5-Methoxy-2-propyl-1H-indole (6n)}

Following general method B, a mixture of $2 \mathbf{e}(0.088 \mathrm{~g}, 1.29 \mathrm{mmol}), \mathbf{1 i}(0.166 \mathrm{~g}, 1.35 \mathrm{mmol})$, and $\mathrm{Hg}_{2} \mathrm{Cl}_{2}(0.028 \mathrm{~g}, 0.06 \mathrm{mmol})$ was stirred at $60^{\circ} \mathrm{C}$ for $2 \mathrm{~h}$. It was then reacted with DMSO $(6.5 \mathrm{~mL}), \mathrm{Cu}(\mathrm{OAc})_{2}(0.352 \mathrm{~g}, 1.94 \mathrm{mmol})$, and $\mathrm{Pd}(\mathrm{OAc})_{2}(0.058 \mathrm{~g}, 0.26 \mathrm{mmol})$ to form $6 \mathbf{n}(0.093 \mathrm{~g}, 38 \%)$ as an amber solid. Rf 0.67 (hexane/EtOAc, 7:3); p.f. $55-56^{\circ} \mathrm{C}$ (Lit. 64-65 ${ }^{\circ} \mathrm{C}$ [107]). IR (ATR): $\overline{\mathrm{v}} 3381,2961,1620,1582,1478,1450,1195,1166,1034,831 \mathrm{~cm}^{-1}$. ${ }^{1} \mathrm{H}$ NMR $\left(500 \mathrm{MHz}, \mathrm{CDCl}_{3}\right): \delta 1.00\left(\mathrm{t}, J=7.5 \mathrm{~Hz}, 3 \mathrm{H}, \mathrm{H}-3^{\prime}\right), 1.73\left(\right.$ hex, $\left.J=7.5 \mathrm{~Hz}, 2 \mathrm{H}, \mathrm{H}-2^{\prime}\right)$, $2.70\left(\mathrm{t}, J=7.5 \mathrm{~Hz}, 2 \mathrm{H}, \mathrm{H}-1^{\prime}\right), 3.84\left(\mathrm{~s}, 3 \mathrm{H}, \mathrm{CH}_{3} \mathrm{O}\right), 6.17(\mathrm{dd}, J=2.0,1.0 \mathrm{~Hz}, 1 \mathrm{H}, \mathrm{H}-3), 6.77(\mathrm{dd}$, $J=8.5,2.5 \mathrm{~Hz}, 1 \mathrm{H}, \mathrm{H}-6), 7.00(\mathrm{~d}, J=2.5 \mathrm{~Hz}, \mathrm{H}-4), 7.18(\mathrm{~d}, J=8.5 \mathrm{~Hz}, 1 \mathrm{H}, \mathrm{H}-7), 7.74(\mathrm{br} \mathrm{s}, 1 \mathrm{H}$, $\mathrm{NH}) .{ }^{13} \mathrm{C}$ NMR $\left(125 \mathrm{MHz}, \mathrm{CDCl}_{3}\right): \delta 13.9\left(\mathrm{C}-3^{\prime}\right), 22.5\left(\mathrm{C}-2^{\prime}\right), 30.4\left(\mathrm{C}-1^{\prime}\right), 55.9\left(\mathrm{CH}_{3} \mathrm{O}\right), 99.5$ (C-3), 102.0 (C-4), 110.7 (C-6), 110.9 (C-7), 129.3 (C-3a), 130.9 (C-7a), 140.7 (C-2), 154.1 (C-5). HRMS (EI): $m / z$ [M $\left[\mathrm{M}^{+}\right]$calcd for $\mathrm{C}_{12} \mathrm{H}_{15} \mathrm{NO}$ : 189.1154 ; found: 189.1153 .

\subsubsection{2-Cyclopropyl-5-methoxy- $1 H$-indole (6o)}

Following general method B, a mixture of $2 \mathbf{f}(0.097 \mathrm{~g}, 1.47 \mathrm{mmol}), \mathbf{1 i}(0.189 \mathrm{~g}, 1.54 \mathrm{mmol})$, and $\mathrm{Hg}_{2} \mathrm{Cl}_{2}(0.033 \mathrm{~g}, 0.07 \mathrm{mmol})$ was stirred at $40{ }^{\circ} \mathrm{C}$ for $2 \mathrm{~h}$. It was then reacted with DMSO (7.3 mL), $\mathrm{Cu}(\mathrm{OAc})_{2}(0.401 \mathrm{~g}, 2.21 \mathrm{mmol})$, and $\mathrm{Pd}(\mathrm{OAc})_{2}(0.065 \mathrm{~g}, 0.29 \mathrm{mmol})$ to provide $6 \mathbf{o}(0.107 \mathrm{~g}, 39 \%)$ as a yellow solid. $R f 0.67$ (hexane/EtOAc, 7:3); mp 57-58 ${ }^{\circ} \mathrm{C}$. IR (ATR): $\bar{v} 3382,2914,1621,1583,1482,1451,1332,1214,1163,1030,837,799,770,676 \mathrm{~cm}^{-1}$. ${ }^{1} \mathrm{H}$ NMR $\left(600 \mathrm{MHz}, \mathrm{CDCl}_{3}\right): \delta 0.73-0.76\left(\mathrm{~m}, 2 \mathrm{H}, \mathrm{CH}_{2}\right), 0.91-0.95\left(\mathrm{~m}, 2 \mathrm{H}, \mathrm{CH}_{2}\right), 1.87-1.93$ $\left(\mathrm{m}, 1 \mathrm{H}, \mathrm{H}-1^{\prime}\right), 6.07(\mathrm{dd}, J=1.2,0.6 \mathrm{~Hz}, 1 \mathrm{H}, \mathrm{H}-3), 6.76(\mathrm{dd}, J=9.0,2.4 \mathrm{~Hz}, 1 \mathrm{H}, \mathrm{H}-6), 6.98(\mathrm{~d}$, $J=2.4 \mathrm{~Hz}, 1 \mathrm{H}, \mathrm{H}-4), 7.13(\mathrm{~d}, J=9.0 \mathrm{~Hz}, 1 \mathrm{H}, \mathrm{H}-7), 7.83(\mathrm{br} \mathrm{s}, 1 \mathrm{H}, \mathrm{NH}) .{ }^{13} \mathrm{C} \mathrm{NMR}(150 \mathrm{MHz}$, $\left.\mathrm{CDCl}_{3}\right): \delta 7.3\left(2 \mathrm{CH}_{2}\right), 8.9\left(\mathrm{C}-1^{\prime}\right), 55.8\left(\mathrm{CH}_{3} \mathrm{O}\right), 97.5(\mathrm{C}-3), 101.9(\mathrm{C}-4), 110.7(\mathrm{C}-6), 110.8(\mathrm{C}-7)$, 129.1 (C-3a), 130.8 (C-7a), 142.6 (C-2), 154.1 (C-5). HRMS (EI): $\mathrm{m} / z$ [M $\left.\mathrm{M}^{+}\right]$calcd for $\mathrm{C}_{12} \mathrm{H}_{13} \mathrm{NO}$ : 187.0997; found: 187.0997 [66]. 


\subsubsection{2-(Cyclohex-1-en-1-yl)-5-methoxy-1H-indole (6p)}

Following general method B, a mixture of $\mathbf{2 g}(0.096 \mathrm{~g}, 0.91 \mathrm{mmol}), \mathbf{1 i}(0.117 \mathrm{~g}, 0.95 \mathrm{mmol})$, and $\mathrm{Hg}_{2} \mathrm{Cl}_{2}(0.024 \mathrm{~g}, 0.05 \mathrm{mmol})$ was stirred at $40{ }^{\circ} \mathrm{C}$ for $2 \mathrm{~h}$. It was then reacted with DMSO $(4.5 \mathrm{~mL}), \mathrm{Cu}(\mathrm{OAc})_{2}(0.247 \mathrm{~g}, 1.36 \mathrm{mmol})$, and $\mathrm{Pd}(\mathrm{OAc})_{2}(0.040 \mathrm{~g}, 0.18 \mathrm{mmol})$ to yield $6 \mathrm{p}(0.037 \mathrm{~g} 18 \%)$ as a brown solid. $R f 0.70$ (hexane/EtOAc, 7:3); $\mathrm{mp} 108-110{ }^{\circ} \mathrm{C}$. IR (KBr): $\bar{v} 3429,2929,1620,1586,1483,1452,1414,1210,1147,1033,837,802,782 \mathrm{~cm}^{-1} .{ }^{1} \mathrm{H}$ NMR (600 MHz, $\left.\mathrm{CDCl}_{3}\right): \delta 1.66-1.71\left(\mathrm{~m}, 2 \mathrm{H}, \mathrm{H}-4^{\prime}\right), 1.76-1.81\left(\mathrm{~m}, 2 \mathrm{H}, \mathrm{H}-5^{\prime}\right), 2.21-2.25(\mathrm{~m}$, $\left.2 \mathrm{H}, \mathrm{H}-3^{\prime}\right), 2.42-2.46\left(\mathrm{~m}, 2 \mathrm{H}, \mathrm{H}-6^{\prime}\right), 6.09-6.11\left(\mathrm{~m}, 1 \mathrm{H}, \mathrm{H}-2^{\prime}\right), 6.37$ (d, J = 1.8 Hz, H-3), 6.80 $(\mathrm{dd}, J=8.6,2.4 \mathrm{~Hz}, 1 \mathrm{H}, \mathrm{H}-6), 7.02(\mathrm{~d}, J=2.4 \mathrm{~Hz}, 1 \mathrm{H}, \mathrm{H}-4), 7.18(\mathrm{~d}, J=8.6 \mathrm{~Hz}, 1 \mathrm{H}, \mathrm{H}-7)$, 7.99 (br s, $1 \mathrm{H}, \mathrm{NH}) .{ }^{13} \mathrm{C}$ NMR $\left(150 \mathrm{MHz}, \mathrm{CDCl}_{3}\right): \delta 22.2\left(\mathrm{C}-4^{\prime}\right), 22.5$ (C-5'), 25.5 (C-3'), 26.0 (C-6'), $55.8\left(\mathrm{CH}_{3} \mathrm{O}\right), 98.5(\mathrm{C}-3), 102.2(\mathrm{C}-4), 111.0(\mathrm{C}-7), 111.9(\mathrm{C}-6), 122.5\left(\mathrm{C}-2^{\prime}\right), 129.1\left(\mathrm{C}-1^{\prime}\right)$, 129.3 (C-3a), 131.3 (C-7a), 140.3 (C-2), 154.1 (C-5). HRMS (EI): $\mathrm{m} / z$ [M $\left.\mathrm{M}^{+}\right]$calcd for $\mathrm{C}_{15} \mathrm{H}_{17} \mathrm{NO}$ : 227.1310; found: 227.1306 .

\subsection{Single-Crystal X-ray Crystallography}

Compounds 5i (yellow crystals, hexane/EtOAc, 98:2), 6e (colorless crystals, hexane/EtOAc, 98:2), and $\mathbf{6 1}$ (pale reddish crystals, hexane/EtOAc, 94:6) were prepared and mounted on glass fibers. Crystallographic measurements were performed with an areadetector with Mo K $\alpha$ diffraction radiation $(\lambda=71,073 \AA$; graphite monochromator) at room temperature (Table 4). Unit cell parameters were obtained from a least-squares refinement. Intensities were corrected for Lorentz and polarization effects. Multi-scan absorption correction was applied. Anisotropic temperature factors were introduced for all non-hydrogen atoms. Hydrogen atoms were placed in accordance with electron density maps and idealized positions, and their atomic coordinates were refined by utilizing unit weights. After the structure was solved using SHELXT [108,109], it was implemented in WinGX [110], refined with SHELXL [111], and then visualized and plotted with the MERCURY program package [112].

Table 4. Crystal data and structure refinement for $5 \mathbf{i}, 6 \mathbf{e}$, and 61 .

\begin{tabular}{|c|c|c|c|}
\hline Structure & $5 i$ & $6 e$ & 61 \\
\hline CCDC number & 2082632 & 2082633 & 2082634 \\
\hline Empirical formula & $\mathrm{C}_{15} \mathrm{H}_{15} \mathrm{NO}$ & $\mathrm{C}_{15} \mathrm{H}_{13} \mathrm{NO}$ & $\mathrm{C}_{16} \mathrm{H}_{12} \mathrm{~N}_{2} \mathrm{O}$ \\
\hline Molecular weight & 225.28 & 223.26 & 248.28 \\
\hline Temperature & $292(2) \mathrm{K}$ & $292(2) \mathrm{K}$ & $292(2) \mathrm{K}$ \\
\hline Crystal size & $0.79 \times 0.47 \times 0.27 \mathrm{~mm}^{3}$ & $0.50 \times 0.30 \times 0.21 \mathrm{~mm}^{3}$ & $0.52 \times 0.30 \times 0.27 \mathrm{~mm}^{3}$ \\
\hline Crystal system & monoclinic & orthorhombic & monoclinic \\
\hline Space group & $\mathrm{P} 2{ }_{1} / \mathrm{n}$ & $\mathrm{P} 2{ }_{1} 2{ }_{1} 2_{1}$ & $P 2_{1} / \mathrm{c}$ \\
\hline $\begin{array}{c}\text { Unit cell } \\
\text { parameters }\end{array}$ & $\begin{array}{c}a=10.0110(6) \AA, \alpha=90^{\circ} \\
b=8.7430(5) \AA, \beta=104.172(7) \\
{ }^{\circ} \mathrm{c}=14.6687(11) \AA, \gamma=90^{\circ}\end{array}$ & $\begin{array}{c}a=5.6782(3) \AA, \alpha=90^{\circ} \\
b=8.0462(3) \AA, \beta=90^{\circ} \\
c=25.5690(16) \AA, \gamma=90^{\circ}\end{array}$ & $\begin{array}{c}a=7.0104(3) \AA, \alpha=90^{\circ} \\
b=14.5242(8) \AA, \beta=98.202(4)^{\circ} \\
c=12.5032(7) \AA, \gamma=90^{\circ}\end{array}$ \\
\hline Volume & $1244.82(14) \AA^{3}$ & $1168.19(11) \AA^{3}$ & $1260.06(11) \AA^{3}$ \\
\hline Z & 4 & 4 & 4 \\
\hline Density & $1.202 \mathrm{mg} / \mathrm{m}^{3}$ & $1.269 \mathrm{mg} / \mathrm{m}^{3}$ & $1.309 \mathrm{mg} / \mathrm{m}^{3}$ \\
\hline Absorption coefficient & $0.075 \mathrm{~mm}^{-1}$ & $0.080 \mathrm{~mm}^{-1}$ & $0.084 \mathrm{~mm}^{-1}$ \\
\hline Theta range & $3.655-29.183^{\circ}$ & $3.187-29.557^{\circ}$ & $2.936-29.453^{\circ}$ \\
\hline Reflections collected & 5094 & 3635 & 5405 \\
\hline Independent reflections & 2839 & 2352 & 2909 \\
\hline Observed reflections & 1999 & 2017 & 2171 \\
\hline Final $R$ indices & $R_{1}=0.0505 ; w R 2=0.1110$ & $R_{1}=0.0387 ; w R 2=0.0841$ & $R_{1}=0.0450 ; w R 2=0.1001$ \\
\hline Goodness-of-fit on $F^{2}$ & 1.042 & 1.056 & 1.022 \\
\hline
\end{tabular}

\section{Conclusions}

A new $\mathrm{Hg}(\mathrm{I})$-catalyzed hydroamination of terminal acetylenes $\mathbf{2 a}-\mathbf{d}$ in the presence of anilines $\mathbf{1 a}-\mathbf{k}$ generated a series of ketimines $\mathbf{5 a}-\mathbf{n}$. An efficient consecutive $\mathrm{Hg}(\mathrm{I}) / \mathrm{Pd}(\mathrm{II})-$ catalyzed one-pot process led to the direct conversion of $\mathbf{1}$ and $\mathbf{2}$ into a series of 2-substituted 
indoles $6 \mathbf{a}-\mathbf{p}$. Although good yields were found for most of the 2-arylindoles, the yields were fairly modest for halogenated, 2-alkyl, and 2-vinyl indoles. The latter limitation was possibly due to the low stability of the imine intermediate under these reaction conditions. Likewise, the direct $\mathrm{Hg}(\mathrm{I})$-catalyzed preparation of the imines either provided low yields or made it impossible to avoid decomposition or hydrolysis to their corresponding acetophenones upon isolation from the reaction mixture. The reaction mechanism of this transformation was explored, finding that an $\mathrm{Hg}(\mathrm{I})-\mathrm{Pd}(\mathrm{II})$ transmetalation step plausibly connects the consecutive cycles of $\mathrm{Hg}(\mathrm{I})$-catalyzed enamine formation and $\mathrm{Pd}(\mathrm{II})$-catalyzed oxidative cyclization.

Supplementary Materials: The following are available online. ${ }^{1} \mathrm{H}$ - and ${ }^{13} \mathrm{C}-\mathrm{NMR}$ spectra are available online. The CIF files of crystal structures have been deposited with the CCDC, and the crystal data and torsion angles for $5 \mathbf{i}, \mathbf{6 e}$, and $\mathbf{6 1}$ are also provided.

Author Contributions: R.U.G. contributed by developing the method, synthesizing compounds, performing NMR and HRMS spectra, and writing the experimental section; M.H.-M. carried out compound synthesis; A.M.-M. performed IR spectra and analyzed the results; F.D. contributed by doing the literature research, analyzing the results, and reviewing the manuscript; J.T. designed the project, provided tutorial guidance, discussed the results, acquired the financial resources, and wrote the manuscript. All authors have read and agreed to the published version of the manuscript.

Funding: The research was supported by the Consejo Nacional de Ciencia y Tecnología (CONACYT, Mexico) (Grants 178319, A1-S-17131, and 300520) and SIP/IPN (Grants 20170902, 20180198, 20195228, 20200227, and 20210700).

Institutional Review Board Statement: Not applicable.

Informed Consent Statement: Not applicable.

Data Availability Statement: Not applicable.

Acknowledgments: We thank M. Fernanda Ramos and Ailyn N. García and CNMN-IPN for their help in spectrometric measurements, and Bruce A. Larsen for proofreading. R.U.G. and M.H.-M. are grateful to CONACYT (SNI) for awarding them graduate and research stay scholarships, and also thank SIP/IPN (BEIFI) and the Ludwig K. Hellweg Foundation for scholarship complements. A.M.-M., F.D., and J.T. are fellows of the EDI-IPN and COFAA-IPN programs.

Conflicts of Interest: The authors declare no conflict of interest.

Sample Availability: Not available.

\section{References}

1. Layer, R.W. The chemistry of imines. Chem. Rev. 1963, 63, 489-510. [CrossRef]

2. Patil, R.D.; Adimurthy, S. Catalytic methods for imine synthesis. Asian J. Org. Chem. 2013, 2, 726-744. [CrossRef]

3. Kim, D.; Kang, B.; Hong, S.H. Ruthenium-catalyzed selective imine synthesis from nitriles and secondary alcohols under hydrogen acceptor- and base-free conditions. Org. Chem. Front. 2016, 3, 475-479. [CrossRef]

4. Amrutham, V.; Mameda, N.; Kodumuri, S.; Chevella, D.; Banothu, R.; Gajula, K.S.; Grigor'eva, N.G.; Nama, N. H 3 Catalyzed condensation reaction between aromatic ketones and anilines: To access ketimines (imines). Catal. Lett. 2017, 147, $2982-2986$. [CrossRef]

5. Zhang, M.; Wu, S.; Bian, L.; Cao, Q.; Fang, W. One-pot synthesis of Pd-promoted Ce-Ni mixed oxides as efficient catalysts for imine production from the direct $N$-alkylation of amine with alcohol. Catal. Sci. Technol. 2019, 9, 286-301. [CrossRef]

6. Carey, A.R.E.; Fukata, G.; O'Ferrall, R.A.M.; Murphy, M.G. The mechanism of imine-enamine tautomerism of 2- and 4phenacylquinolines. J. Chem. Soc. Perkin Trans. 1985, 1711-1722. [CrossRef]

7. Capon, B.; Wu, Z.-P. Comparison of the tautomerization and hydrolysis of some secondary and tertiary enamines. J. Org. Chem. 1990, 55, 2317-2324. [CrossRef]

8. Ciaccia, M.; Di Stefano, S. Mechanisms of imine exchange reactions in organic solvents. Org. Biomol. Chem. 2015, 13, 646-654. [CrossRef]

9. Wang, X.; Zhang, Y.; Tan, H.; Wang, Y.; Han, P.; Wang, D.Z. Enantioselective organocatalytic Mannich reactions with autocatalysts and their mimics. J. Org. Chem. 2010, 75, 2403-2406. [CrossRef]

10. Kutlescha, K.; Venkanna, G.T.; Kempe, R. The potassium hydride mediated trimerization of imines. Chem. Commun. 2011, 47, 4183-4185. [CrossRef] 
11. Yang, Z.; He, W.; Cheng, B.; Xu, J. Stereochemistry and mechanistic insight in the [2k+2i+2i] annulations of ketenes and imines. J. Org. Chem. 2016, 81, 4506-4515. [CrossRef]

12. Wu, P.; Givskov, M.; Nielsen, T.E. Reactivity and synthetic applications of multicomponent Petasis reactions. Chem. Rev. 2019, 119, 11245-11290. [CrossRef]

13. Mir, H.; Ahmed, D. Synthesis of Schiff bases of acetophenone with aniline and its different chloro-substituted derivatives, and study of their antioxidant, enzyme inhibitory and antimicrobial properties. J. Chem. Soc. Pak. 2016, 38, 981-989.

14. da Silva, C.M.; da Silva, D.L.; Modolo, L.V.; Alves, R.B.; de Resende, M.A.; Martins, C.V.B.; de Fátima, A. Schiff bases: A short review of their antimicrobial activities. J. Adv. Res. 2011, 2, 1-8. [CrossRef]

15. da Silva, E.T.; da Silva Araújo, A.; Moraes, A.M.; de Souza, L.A.; Silva Lourenço, M.C.; de Souza, M.V.N.; Wardell, J.L.; Wardell, M.S.V. Synthesis and biological activities of camphor hydrazone and imine derivatives. Sci. Pharm. 2016, 84, 467. [CrossRef] [PubMed]

16. Hille, A.; Ott, I.; Kitanovic, A.; Kitanovic, I.; Alborzinia, H.; Lederer, E.; Wölfl, S.; Metzler-Nolte, N.; Schäfer, S.; Sheldrick, W.S.; et al. [N,N'-Bis(salicylidene)-1,2-phenylenediamine]metal complexes with cell death promoting properties. J. Biol. Inorg. Chem. 2009, 14, 711-725. [CrossRef]

17. Hille, A.; Gust, R. Influence of methoxy groups on the antiproliferative effects of [Fe ${ }^{\mathrm{III}}$ (salophene-OMe)Cl] complexes. Eur. J. Med. Chem. 2010, 45, 5486-5492. [CrossRef] [PubMed]

18. Kim, K.K.; Singh, R.K.; Strongin, R.M.; Moore, R.G.; Brard, L.; Lange, T.S. Organometallic iron(III)-salophene exerts cytotoxic properties in neuroblastoma cells via MAPK activation and ROS generation. PLoS ONE 2011, 6, e19049. [CrossRef] [PubMed]

19. Siddiqui, A.; Dandawate, P.; Rub, R.; Padhye, S.; Aphale, S.; Moghe, A.; Jagyasi, A.; Swamy, K.V.; Singh, B.; Chatterjee, A.; et al. Novel aza-resveratrol analogs: Synthesis, characterization and anticancer activity against breast cancer cell lines. Bioorg. Med. Chem. Lett. 2013, 23, 635-640. [CrossRef]

20. Abdalla, F.; Nookala, A.; Padhye, S.B.; Kumar, A.; Bhat, H.K. 4-€-\{(p-Tolylimino)-methylbenezene-1,2-diol\} (TIMBD) suppresses HIV1-gp120 mediated production of IL6 and IL8 but not CCL5. Sci. Rep. 2017, 7, 8129. [CrossRef]

21. Stivala, C.E.; Benoit, E.; Aráoz, R.; Servent, D.; Novikov, A.; Molgó, J.; Zakarian, A. Synthesis and biology of cyclic imine toxins, an emerging class of potent, globally distributed marine toxins. Nat. Prod. Rep. 2015, 32, 411-435. [CrossRef]

22. Kochanowska-Karamyan, A.J.; Hamann, M.T. Marine indole alkaloids: Potential new drug leads for the control of depression and anxiety. Chem. Rev. 2010, 110, 4489-4497. [CrossRef] [PubMed]

23. Williams, R.B.; Hu, J.-F.; Olson, K.M.; Norman, V.L.; Goering, M.G.; O’Neil-Johnson, M.; Eldridge, G.R.; Starks, C.M. Antibiotic indole sesquiterpene alkaloid from Greenwayodendron suaveolens with a new natural product framework. J. Nat. Prod. 2010, 73 , 1008-1011. [CrossRef] [PubMed]

24. Ciulla, M.G.; Kumar, K. The natural and synthetic indole weaponry against bacteria. Tetrahedron Lett. 2018, 59, 3223-3233. [CrossRef]

25. Leboho, T.C.; Michael, J.P.; van Otterlo, W.A.L.; van Vuuren, S.F.; de Koning, C.B. The synthesis of 2- and 3-aryl indoles and 1,3,4,5-tetrahydropyrano [4,3-b]indoles and their antibacterial and antifungal activity. Bioorg. Med. Chem. Lett. 2009, 19, 4948-4951. [CrossRef]

26. Kaushik, N.K.; Kaushik, N.; Attri, P.; Kumar, N.; Kim, C.H.; Verma, A.K.; Choi, E.H. Biomedical importance of indoles. Molecules 2013, 18, 6620-6662. [CrossRef]

27. Melander, R.J.; Minvielle, M.J.; Melander, C. Controlling bacterial behavior with indole-containing natural products and derivatives. Tetrahedron 2014, 70, 6363-6372. [CrossRef]

28. Han, X.; Wu, H.; Wang, W.; Dong, C.; Tien, P.; Wu, S.; Zhou, H.-B. Synthesis and SARs of indole-based $\alpha$-amino acids as potent HIV-1 non-nucleoside reverse transcriptase inhibitors. Org. Biomol. Chem. 2014, 12, 8308-8317. [CrossRef]

29. Sanphui, P.; Bolla, G.; Das, U.; Mukherjee, A.K.; Nangia, A. Acemetacin polymorphs: A rare case of carboxylic acid catemer and dimer synthons. CrystEngComm 2013, 15, 34-38. [CrossRef]

30. Zhang, M.-Z.; Chen, Q.; Yang, G.-F. A review on recent developments of indole-containing antiviral agents. Eur. J. Med. Chem. 2015, 89, 421-441. [CrossRef]

31. Wright, Z.V.F.; Wu, N.C.; Kadam, R.U.; Wilson, I.A.; Wolan, D.W. Structure-based optimization and synthesis of antiviral drug Arbidol analogues with significantly improved affinity to influenza hemagglutinin. Bioorg. Med. Chem. Lett. 2017, 27, 3744-3748. [CrossRef] [PubMed]

32. Wishart, D.S.; Knox, C.; Guo, A.C.; Shrivastava, S.; Hassanali, M.; Stothard, P.; Chang, Z.; Woolsey, J. DrugBank: A comprehensive resource for in silico drug discovery and exploration. Nucleic Acids Res. 2006, 34, D668-D672. [CrossRef] [PubMed]

33. Vitaku, E.; Smith, D.T.; Njardarson, J.T. Analysis of the structural diversity, substitution patterns, and frequency of nitrogen heterocycles among U.S. FDA approved pharmaceuticals. J. Med. Chem. 2014, 57, 10257-10274. [CrossRef] [PubMed]

34. Wang, X.; Cao, R.; Zhang, H.; Liu, J.; Xu, M.; Hu, H.; Li, Y.; Zhao, L.; Li, W.; Sun, X.; et al. The anti-influenza virus drug, arbidol is an efficient inhibitor of SARS-CoV-2 in vitro. Cell Discov. 2020, 6, 28-32. [CrossRef]

35. Zhu, Z.; Lu, Z.; Xu, T.; Chen, C.; Yang, G.; Zha, T.; Lu, J.; Xue, Y. Arbidol monotherapy is superior to lopinavir/ritonavir in treating COVID-19. J. Infect. 2020, 81, e21-e23. [CrossRef] [PubMed]

36. Tao, Y.; Tang, L.V.; Hu, Y. Treatment in the COVID-19 pandemic: An update on clinical trials. Expert Opin. Emerg. Drugs 2020, 25, 81-88. [CrossRef] [PubMed] 
37. Yang, C.; Ke, C.; Yue, D.; Li, W.; Hu, Z.; Liu, W.; Hu, S.; Wang, S.; Liu, J. Effectiveness of arbidol for COVID-19 prevention in health professionals. Front. Public Health 2020, 8, 249. [CrossRef] [PubMed]

38. Barton, D.H.R.; Motherwell, W.B.; Simon, E.S.; Zard, S.Z. Reduction of oximes and aliphatic nitro compounds to imines for further in situ reactions: A novel synthesis of pyrroles and pyrrolin-2-ones. J. Chem. Soc. Perkin Trans. I 1986, 2243-2252. [CrossRef]

39. Kitamura, M.; Zaman, S.; Narasaka, K. Synthesis of spiro imines from oximes by palladium-catalyzed cascade reaction. Synlett 2001, SI, 974-976. [CrossRef]

40. Huang, F.; Zhang, S. Iminyl radicals by reductive cleavage of N-O bond in oxime ether promoted by SmI 2 : A straightforward synthesis of five-membered cyclic imines. Org. Lett. 2019, 21, 7430-7434. [CrossRef]

41. Chakraborty, S.; Milstein, D. Selective hydrogenation of nitriles to secondary imines catalyzed by an iron pincer complex. ACS Catal. 2017, 7, 3968-3972. [CrossRef]

42. Weiberth, F.J.; Hall, S.S. Copper(I)-activated addition of Grignard reagents to nitriles. Synthesis of ketimines, ketones, and amines. J. Org. Chem. 1987, 52, 3901-3904. [CrossRef]

43. Feringa, B.L.; Jansen, J.F.G.A. A new synthesis of imines via Grignard- and cuprate additions to $N$-trimethylsilylformamides. Synthesis 1988, 3, 184-186. [CrossRef]

44. Maggi, A.; Madsen, R. Dehydrogenative synthesis of imines from alcohols and amines catalyzed by a ruthenium N-heterocyclic carbene complex. Organometallics 2012, 31, 451-455. [CrossRef]

45. Chen, B.; Wang, L.; Gao, S. Recent advances in aerobic oxidation of alcohols and amines to imines. ACS Catal. 2015, 5, 5851-5876. [CrossRef]

46. Bennett, J.; Meldi, K.; Kimmell, C., II. Synthesis and analysis of a versatile imine for the undergraduate organic chemistry laboratory. J. Chem. Educ. 2006, 83, 1221-1224. [CrossRef]

47. Look, G.C.; Murphy, M.M.; Campbell, D.A.; Gallop, M.A. Trimethylorthoformate: A mild and effective dehydrating reagent for solution and solid phase imine formation. Tetrahedron Lett. 1995, 36, 2937-2940. [CrossRef]

48. Mirabdolbaghi, R.; Dudding, T. Expanding the forefront of strong organic Brønsted acids: Proton-catalyzed hydroamination of unactivated alkenes and activation of $\mathrm{Au}(\mathrm{I})$ for alkyne hydroamination. Org. Lett. 2015, 17, 1930-1933. [CrossRef]

49. Mir, R.; Dudding, T.A. Au(I)-precatalyst with a cyclopropenium counterion: An unusual ion pair. J. Org. Chem. 2016, 81, 2675-2679. [CrossRef]

50. Nagata, T.; Adachi, Y.; Obora, Y. Thiolate-protected $\mathrm{Au}_{25}\left(\mathrm{SC}_{2} \mathrm{H}_{4} \mathrm{Ph}\right)_{18}$ nanoclusters as a catalyst for intermolecular hydroamination of terminal alkynes. Synlett 2018, 29, 2655-2659.

51. Casnati, A.; Voronov, A.; Ferrari, D.G.; Mancuso, R.; Gabriele, B.; Motti, E.; Della Ca', N. PdI 2 as a simple and efficient catalyst for the hydroamination of arylacetylenes with anilines. Catalysts 2020, 10, 176. [CrossRef]

52. Barluenga, J.; Aznar, F.; Valdés, C.; Cabal, M.-P. Catalytic aminomercuration reactions of 3-alken-1-ynes: An improved method for the synthesis of 2-amino-1,3-butadienes and 1-aza-1,3-butadienes. J. Org. Chem. 1991, 56, 6166-6171. [CrossRef]

53. Barluenga, J.; Aznar, F.; Liz, R.; Rodes, R. Catalytic and non-catalytic additions of aromatic amines to terminal acetylenes in the presence of mercury(II) chloride and acetate. J. Chem. Soc. Perkin Trans. I 1980, 2732-2737. [CrossRef]

54. Barluenga, J.; Aznar, F.; Liz, R.; Rodes, R. Alkynylmercury chloride or acetate as intermediates in the mercury(II) salt-promoted addition of aliphatic and aromatic amines to terminal acetylenes. J. Chem. Soc. Perkin Trans. I 1983, 1087-1091. [CrossRef]

55. Gribble, G.W. Indole Ring Synthesis from Natural Products to Drugs Discovery; John Wiley \& Sons Ltd.: Chichester, UK, 2016.

56. Wagaw, S.; Yang, B.H.; Buchwald, S.L. A palladium-catalyzed method for the preparation of indoles via the Fischer indole synthesis. J. Am. Chem. Soc. 1999, 121, 10251-10263. [CrossRef]

57. Heravi, M.M.; Rohani, S.; Zadsirjan, V.; Zahedi, N. Fischer indole synthesis applied to the total synthesis of natural products. RSC Adv. 2017, 7, 52852. [CrossRef]

58. Baudin, J.-B.; Julia, S.A. Synthesis of indoles from N-aryl-1-alkenylsuphinamides. Tetrahedron Lett. 1986, 27, 837-840. [CrossRef]

59. Bartoli, G.; Dalpozzo, R.; Nardi, M. Applications of Bartoli indole synthesis. Chem. Soc. Rev. 2014, 43, 4728-4750. [CrossRef]

60. Gassman, P.G.; van Bergen, T.J.; Gruetzmacher, G. Use of halogen-sulfide complexes in the synthesis of indoles, oxindoles, and alkylated aromatic amines. J. Am. Chem. Soc. 1973, 95, 6508-6509. [CrossRef]

61. Castro, C.E.; Gaughan, E.J.; Owsley, D.C. Indoles, benzofurans, phthalides, and tolanes via copper(I) acetylides. J. Org. Chem. 1966, 31, 4071-4078. [CrossRef]

62. Larock, R.C.; Yum, E.K.; Refvik, M.D. Synthesis of 2,3-disubstituted indoles via palladium-catalyzed annulation of internal alkynes. J. Org. Chem. 1998, 63, 7652-7662. [CrossRef]

63. Huestis, M.P.; Chan, L.; Stuart, D.R.; Fagnou, K. The vinyl moiety as a handle for regiocontrol in the preparation of unsymmetrical 2,3-aliphatic-susbtituted indoles and pyrroles. Angew. Chem. Int. Ed. 2011, 50, 1338-1341. [CrossRef] [PubMed]

64. Ansari, N.H.; Dacko, C.A.; Akhmedov, N.G.; Söderberg, B.C.G. Double palladium catalyzed reductive cyclizations. Synthesis of 2,2'-, 2,3', and 3,3'-bi-1H-indoles, indolo[3,2-b]indoles, and indolo[2,3-b]indoles. J. Org. Chem. 2016, 81, 9337-9349. [CrossRef] [PubMed]

65. Ansari, N.H.; Banini, S.; Cummings, M.M.; Söderberg, B.C.G. Palladium catalyzed double reductive cyclization of 2,3-dinitro-1,4dialkenylbenzenes. Synthesis of 1H,8H-pyrrolo[3,2-g]indoles. J. Org. Chem. 2020, 85, 4002-4010. [CrossRef]

66. Wei, Y.; Deb, I.; Yoshikai, N. Palladium-catalyzed aerobic oxidative cyclization of N-aryl imines: Indoles synthesis from anilines and ketones. J. Am. Chem. Soc. 2012, 134, 9098-9101. [CrossRef] [PubMed] 
67. Ren, L.; Nan, G.; Wang, Y.; Xiao, Z. Carboxylic acid promoted single-step indole construction from simple anilines and ketones via aerobic cross-dehydrogenative coupling. J. Org. Chem. 2018, 83, 14472-14488. [CrossRef] [PubMed]

68. Jiang, T.-S.; Dai, L.; Zhou, Y.; Zhang, X. Palladium-catalyzed tandem oxidative annulation of $\alpha$-amino ketones leading to 2-aroylindoles. Tetrahedron 2020, 76, 130917. [CrossRef]

69. Bautista, R.; Montoya, P.A.; Rebollar, A.; Burgueño, E.; Tamariz, J. Palladium-catalyzed synthesis of natural and unnatural 2-, 5-, and 7-oxygenated carbazole alkaloids from $N$-arylcyclohexane enaminones. Molecules 2013, 18, 10334-10351. [CrossRef]

70. Labarrios, E.; Jerezano, A.; Jiménez, F.; Cruz, M.C.; Delgado, F.; Zepeda, L.G.; Tamariz, J. Efficient synthetic approach to substituted benzo[b]furans and benzo[b]thiophenes by iodine-promoted cyclization of enaminones. J. Heterocycl. Chem. 2014, 51, 954-971. [CrossRef]

71. Espinoza-Hicks, C.; Montoya, P.; Bautista, R.; Jiménez-Vázquez, H.A.; Rodríguez-Valdez, L.M.; Camacho-Dávila, A.A.; Cossío, F.P.; Delgado, F.; Tamariz, J. Synthesis of exo-imidazolidin-2-one dienes, their isomerization, and selectivity in Diels-Alder cycloadditions. J. Org. Chem. 2018, 83, 5347-5364. [CrossRef] [PubMed]

72. Cruz, M.C.; Jiménez, F.; Delgado, F.; Tamariz, J. Regioselective and versatile synthesis of indoles via intramolecular Friedel-Crafts heteroannulation of enaminones. Synlett 2006, 5, 749-755.

73. Jerezano, A.V.; Labarrios, E.M.; Jiménez, F.E.; Cruz, M.C.; Pazos, D.C.; Gutiérrez, R.U.; Delgado, F.; Tamariz, J. Iodine-mediated one-pot synthesis of indoles and 3-dimethylaminoindoles via annulation of enaminones. Arkivoc 2014, iii, 18-53. [CrossRef]

74. Hernández-Benitez, R.I.; Zárate-Zárate, D.; Delgado, F.; Tamariz, J. Palladium-catalyzed synthesis of diarylamines and 1- and 2-oxygenated carbazoles: Total syntheses of natural alkaloids clauraila A, clausenal, clausine P, and 7-methoxy-O-methylmukonal. Synthesis 2017, 49, 4357-4371.

75. Escalante, C.H.; Martínez-Mora, E.I.; Espinoza-Hicks, C.; Camacho-Dávila, A.A.; Ramos-Morales, F.R.; Delgado, F.; Tamariz, J. Highly selective Diels-Alder and Heck arylation reactions in a divergent synthesis of isoindolo- and pyrrolo-fused polycyclic indoles from 2-formylpyrrole. Beilstein J. Org. Chem. 2020, 16, 1320-1334. [CrossRef]

76. Gryff-Keller, A.; Kraska-Dziadecka, A.; Molchanov, S.; Wodyński, A. Shielding and indirect spin-spin coupling tensors in the presence of a heavy atom: An experimental and theoretical study of bis(phenylethynyl)mercury. J. Phys. Chem. A 2012, 116, 10615-10620. [CrossRef] [PubMed]

77. Kadam, A.R.; Nair, G.B.; Dhoble, S.J. Insights into the extraction of mercury from fluorescent lamps: A review. J. Environ. Chem. Eng. 2019, 7, 103279. [CrossRef]

78. Ozkan, S.A.; Uslu, B. From mercury to nanosensors: Past, present and the future perspective of electrochemistry in pharmaceutical biomedical analysis. J. Pharm. Biomed. Anal. 2016, 130, 126-140. [CrossRef]

79. Hutchings, G.J.; Grady, D.T. Hydrochlorination of acetylene: The effect of mercuric chloride concentration on catalyst life. Appl. Catal. 1985, 17, 155-160. [CrossRef]

80. Larock, R.C. Organomercurials in organic synthesis. Tetrahedron 1982, 38, 1713-1754. [CrossRef]

81. Larock, R.C. Organomercury Compounds in Organic Synthesis. In Reactivity and Structure Concepts in Organic Chemistry; Hafner, K., Lehn, J.-M., Rees, C.W., von Ragué Schleyer, P., Trost, B.M., Zahradnik, R., Eds.; Springer: Berlin, Germany, 1985 ; Volume 22.

82. Zheng, M.; Chen, K.; Zhu, S. One-pot synthesis of indole derivatives from the reaction of nitroalkynes and alkynes via mercurycarbene intermediate. Synthesis 2017, 49, 4173-4182.

83. Pun-Hua, L.; Lei, W. Mercurous chloride catalyzed Mannich condensation of terminal alkynes with secondary amines and aldehydes. Chin. J. Chem. 2005, 23, 1076-1080. [CrossRef]

84. Dehghanpour, S.; Jahani, K.; Mahmoudi, A.; Babakhodaverdi, M.; Notash, B. In situ hydrothermal synthesis of 2D mercury(I)organic framework from 3-aminopyrazine-2-carboxylic acid and mercury(II) acetate. Inorg. Chem. Commun. 2012, 25, 79-82. [CrossRef]

85. Gutiérrez, R.U.; Correa, H.C.; Bautista, R.; Vargas, J.L.; Jerezano, A.V.; Delgado, F.; Tamariz, J. Regioselective synthesis of 1,2-dihydroquinolines by a solvent-free $\mathrm{MgBr}_{2}$-catalyzed multicomponent reaction. J. Org. Chem. 2013, 78, 9614-9626. [CrossRef]

86. Zangade, S.; Patil, P. A review on solvent-free methods in organic synthesis. Curr. Org. Chem. 2019, 23, 2295-2318. [CrossRef]

87. Ol'dekop, Y.A.; Maier, N.A. Decarboxylation of mercury salts of organic acids under the action of peroxides and ultraviolet radiation. Russ. Chem. Bull. 1966, 15, 1127-1132. [CrossRef]

88. Whitesides, G.M.; Hackett, M.; Brainard, R.L.; Lavalleye, J.-P.P.M.; Sowinski, A.F.; Izumi, A.N.; Moore, S.S.; Brown, D.W.; Satudt, E.M. Suppression of unwanted heterogeneous platinum(0)-catalyzed reactions by poisoning with mercury $(0)$ in systems involving competing homogeneous reactions of soluble organoplatinum compounds: Thermal decomposition of bis(triethylphosphine)3,3,4,4-tetramethylplatinacyclopentane. Organometallics 1985, 4, 1819-1830.

89. Guan, Z.-H.; Yan, Z.-Y.; Ren, Z.-H.; Liu, X.-Y.; Liang, Y.-M. Preparation of indoles via iron catalyzed direct oxidative coupling. Chem. Commun. 2010, 46, 2823-2825. [CrossRef]

90. Neumann, J.J.; Rakshit, S.; Dröge, T.; Würtz, S.; Glorius, F. Exploring the oxidative cyclization of substituted N-aryl enamines: Pd-catalyzed formation of indoles from anilines. Chem. Eur. J. 2011, 17, 7298-7303. [CrossRef]

91. Shi, Z.; Zhang, C.; Li, S.; Pan, D.; Ding, S.; Cui, Y.; Jiao, N. Indoles from simple anilines and alkynes: Palladium-catalyzed C-H activation using dioxygen as the oxidant. Angew. Chem. Int. Ed. 2009, 48, 4572-4576. [CrossRef] [PubMed]

92. Larock, R.C.; Harrison, L.W.; Hsu, M.H. Heteroannulation vis intramolecular (p-allyl)palladium displacement. J. Org. Chem. 1984, 49, 3662-3664. [CrossRef] 
93. Larock, R.C.; Riefling, B.; Fellows, C.A. Mercury in organic chemistry. 12. Synthesis of $\beta$-chloro- $\Delta^{\alpha, \beta}$-buetnolides via mercurationcarbonylation of propargylic alcohols. J. Org. Chem. 1984, 49, 131-137.

94. Siemsen, P.; Livingston, R.C.; Diederich, F. Acetylenic coupling: A powerful tool in molecular construction. Angew. Chem. Int. Ed. 2000, 39, 2632-2657. [CrossRef]

95. Gautier, F.-M.; Jones, S.; Martin, S.J. Asymmetric reduction of ketimines with trichlorosilane employing an imidazole derived organocatalyst. Org. Biomol. Chem. 2009, 7, 229-231. [CrossRef]

96. Erken, C.; Hindemith, C.; Weyhermüller, T.; Hölscher, M.; Werlé, C.; Leitner, W. Hydroamination of aromatic alkynes to imines catalyzed by Pd(II)-anthraphos complexes. ACS Omega 2020, 5, 8912-8918. [CrossRef] [PubMed]

97. Liu, X.-Y.; Ding, P.; Huang, J.-S.; Che, C.-M. Synthesis of substituted 1,2-dihydroquinolines and quinolines from aromatic amines and alkynes by gold(I)-catalyzed tandem hydroamination-hydroarylation under microwave-assisted conditions. Org. Lett. 2007, 9, 2645-2648. [CrossRef]

98. Yoshii, R.; Hirose, A.; Tanaka, K.; Chujo, Y. Functionalization of boron diiminates with unique optical properties: Multicolor tuning of crystallization-induced emission and introduction into the main chain of conjugated polymers. J. Am. Chem. Soc. 2014, 136, 18131-18139. [CrossRef]

99. Imamoto, T.; Iwadate, N.; Yoshida, K.E. Enantioselective hydrogenation of acyclic aromatic $N$-aryl imines catalyzed by an iridium complex of (S,S)-1,2-bis(tert-butylmethylphosphino)ethane. Org. Lett. 2006, 8, 2289-2292. [CrossRef]

100. Suslick, B.A.; Tilley, T.D. Olefin hydroarylation catalyzed by a single-component cobalt(-I) complex. Org. Let. 2021, 23, 1495-1499. [CrossRef]

101. Deprez, N.R.; Kalyani, D.; Krause, A.; Sanford, M.S. Room temperature palladium-catalyzed 2-arylation of indoles. J. Am. Chem. Soc. 2006, 128, 4972-4973. [CrossRef]

102. Shen, M.; Leslie, B.E.; Driver, T.G. Dirhodium-catalyzed intramolecular C-H amination of aryl azides. Angew. Chem. Int. Ed. 2008, 47, 5056-5059. [CrossRef]

103. Xia, X.-D.; Xuan, J.; Wang, Q.; Lu, L.-Q.; Chen, J.-R.; Xiao, W.-J. Synthesis of 2-substituted indoles through visible light-induced photocatalytic cyclizations of styryl azides. Adv. Synth. Catal. 2014, 356, 2807-2812. [CrossRef]

104. Liu, C.; Ding, D.; Guo, G.; Liu, W.; Yang, F.-L. Palladium-catalyzed direct arylation of indoles with arylsulfonyl hydrazides. Org. Biomol. Chem. 2016, 14, 2824-2827. [CrossRef] [PubMed]

105. Wang, H.; Li, Y.; Jiang, L.; Zhang, R.; Jin, K.; Zhao, D.; Duan, C. Ready synthesis of free N-H 2-arylindoles via the copper-catalyzed amination of 2-bromo-arylacetylenes with aqueous ammonia and sequential intramolecular cyclization. Org. Biomol. Chem. 2011, 9, 4983-4986. [CrossRef] [PubMed]

106. Cacchi, S.; Fabrizi, G.; Goggiamani, A.; Iazetti, A.; Verdiglione, R. A facile palladium-catalyzed route to 2,5,7-trisubstituted indoles. Tetrahedron 2015, 71, 9346-9356. [CrossRef]

107. Trabbic, C.J.; Dietsch, H.M.; Alexander, E.M.; Nagy, P.I.; Robinson, M.W.; Overmeyer, J.H.; Maltese, W.A.; Erhardt, P.W. Differential induction of cytoplasmic vacuolization and methuosis by novel 2-indolyl-substituted pyridinylpropenones. ACS Med. Chem. Lett. 2014, 5, 73-77. [CrossRef]

108. Sheldrick, G.M. A short history of SHELX. Acta Crystallogr. Sect. A 2008, 64, 112-122. [CrossRef]

109. Sheldrick, G.M. SHELXT-Integrated space-group and crystal-structure determination. Acta Crystallogr. Sect. A 2015, 71, 3-8. [CrossRef]

110. Farrugia, L.J. WinGX suite for small-molecule single-crystal crystallography. J. Appl. Crystallogr. 1999, 32, 837-838. [CrossRef]

111. Sheldrick, G.M. Crystal structure refinement with SHELXL. Acta Cryst. 2015, C71, 3-8.

112. Macrae, C.F.; Sovago, I.; Cottrell, S.J.; Galek, P.T.A.; McCabe, P.; Pidcock, E.; Platings, M.; Shields, G.P.; Stevens, J.S.; Towler, M.; et al. Mercury 4.0: From visualization to analysis, design and prediction. J. Appl. Cryst. 2020, 53, 226-235. [CrossRef] 